\title{
Sequence stratigraphy, paleogeography, and coal accumulation regularity of major coal-accumulating periods in China
}

\author{
Longyi Shao $^{1}\left(\mathbb{C} \cdot\right.$ Xuetian Wang $^{1} \cdot$ Dongdong Wang $^{1,2} \cdot{\text { Mingpei } \mathrm{Li}^{1,3}}$. \\ Shuai Wang ${ }^{1} \cdot{\text { Yingjiao } \mathrm{Li}^{1} \cdot \text { Kai Shao }}^{1,4} \cdot$ Chao Zhang $^{1} \cdot$ Caixia Gao $^{1}$.

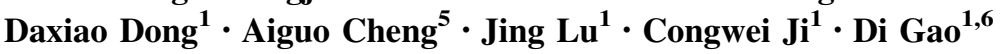

Received: 17 August 2019/Revised: 5 June 2020/Accepted: 15 June 2020/Published online: 13 July 2020

(C) The Author(s) 2020

\begin{abstract}
There are 9 major coal-accumulating periods during geological history in China, including the Early Carboniferous, Late Carboniferous-Early Permian, Middle Permian, Late Permian, Late Triassic, Early-Middle Jurassic, Early Cretaceous, Paleogene and Neogene. The coal formed in these periods were developed in different coal-accumulating areas (CAA) including the North China, South China, Northwest China, Northeast China, the Qinghai-Tibet area, and China offshore area. In this paper, we investigated depositional environments, sequence stratigraphy, lithofacies paleogeography and coal accumulation pattern of five major coal-accumulating periods including the Late Carboniferous to Middle Permian of the North China CAA, the Late Permian of the South China CAA, the Late Triassic of the South China CAA, the Early-Middle Jurassic of the North and Northwest China CAA, and the Early Cretaceous in the Northeast China CAA. According to distribution of the coal-bearing strata and the regional tectonic outlines, we have identified distribution range of the coal-forming basins, sedimentary facies types and coal-accumulating models. The sequence stratigraphic frameworks of the major coal-accumulating periods were established based on recognition of a variety of sequence boundaries. The distribution of thick coals and migration patterns of the coal-accumulating centers in the sequence stratigraphic framework were analyzed. The lithofacies paleogeography maps based on third-order sequences were reconstructed and the distribution of coal accumulation centers and coal-rich belts were predicted.
\end{abstract}

Keywords Coal-accumulating period $\cdot$ Coal-accumulating area $\cdot$ Sequence stratigraphy $\cdot$ Paleogeography $\cdot$ China

Longyi Shao

ShaoL@cumtb.edu.cn

1 State Key Laboratory of Coal Resources and Safe Mining, College of Geoscience and Surveying Engineering, China University of Mining and Technology (Beijing), Beijing 100083, China

2 College of Earth Science and Engineering, Shandong University of Science and Technology,

Qingdao 266590, Shandong, China

3 Innovation Technology Research Institute of Shaanxi Investment Group Co., Ltd., Xi' an 710061, Shaanxi, China

4 Shaanxi Coalbed Methane Development Company Limited, Xi'an 710119, Shaanxi, China

5 China National Administration of Coal Geology, Beijing 100039, China

6 College of Resources and Environment, Henan Polytechnic University, Jiaozuo 454003, Henan, China

\section{Introduction}

China is one of the major coal resource countries in the world, with a total of 5.9 trillion tons of shallow coal resources less than $2000 \mathrm{~m}$ in depth, including 2.02 trillion tons of discovered resources (reserves) and 3.88 trillion predicted resources (Cheng 2016). China is also the largest coal producer and consumer in the world. In China, coal production accounted for $69.3 \%$ of total energy production and coal consumption accounted for 59\% of total energy consumption in 2018 (China Statistic Department 2019). It is obvious that coal is still the primary energy in China, and with the rapid development of national economy, the energy guarantee for the national economy will continue to rely on the coal resources. Understanding of the geological distribution of coal resources is a crucial pathway for the prediction and prospection of more coal resources. 
The accumulation of coal was controlled by paleobotanical community, paleogeography, paleotectonics, and paleoclimates, and the occurrence of coal in geological history showed a clear cyclic and periodic pattern (Horne et al. 1978; Han and Yang 1980; Fielding 1987; Li 1988; Peng 1990; Chen et al. 1993; Zhang 1995; Wang 1996a; Cheng et al. 2001). Lithofacies paleogeographic analysis is an important method for analyzing coal accumulation regularity (Hsieh 1949). Sequence stratigraphy provides an isochronous stratigraphic framework for paleogeographic analysis (Shao et al. 2008, 2009). Sequence-paleogeographic map can be reconstructed within the isochronous sequence stratigraphic units, and by compiling sequencepaleogeographic maps, the distribution and migration of coal-accumulating centers, and coal-rich belts can be predicted (Shao et al. 2017).

In China, five nation-wide coal resource assessments have been carried out since 1949. The first coal resource assessment, with a formal name of "First Nation-wide Coalfield Prediction", was carried out by Ministry of Coal Industry during 1958-1959. In addition to estimate the statistical coal resources for the first time, it also accomplished with a published monograph "China Coal Field Geology" (1961). The second coal resource assessment, with a formal name of "Second Nation-wide Coalfield Prediction", was carried out by Coal Geology Administration of the Ministry of Coal Industry during 1973-1980. In this prediction, the geomechanics theory was widely applied, and two volumes of monograph "Coalfield Geology in China" were published (Yang and Han 1979; Han and Yang 1980). The third coal resource assessment, with a formal name of "Third Nationwide Coalfield Prediction", was carried out by the China National Administration of Coal Geology during 1992-1997. The sedimentary paleogeography theory is widely used for analyzing coal accumulation regularity of different coal-accumulating periods, and these works have been well summarized in several important published monographs, including the "Prediction and Assessment of Coal Resource in China", "Review of Coal Quality in China", and "China Coal-Accumulation Systems", together with several other monographs describing the provincial coal accumulation in different coal-accumulating periods. Another coal resource assessment led by Ministry of Geology and Mineral Resources during 1983-1988, has a formal name of "Nation-wide Prospective Survey of Coal Resources". The results of this work have been summed up in a seven-volume of monograph series including "General Remarks of Coal Resources in China" and "Depositional Environment and Coal-Accumulating Regularities of Main Coal-Accumulating Stages in China". The latest round of coal resource assessment, which has a formal name of "Nation-wide Assessment of Coal Resource Potentials in China", was led by the Ministry of Land and Resources and conducted by the China National Administration of Coal Geology in collaboration with China University of Mining and Technology (Beijing) in 2007-2012. In this newest study on coal resource assessment, the sequence stratigraphy theory was used to establish the synchronous stratigraphic framework and to reconstruct the paleogeography under the synchronous sequence stratigraphic units for the different coal-accumulating periods.

During these five nation-wide coal resource assessments, the sedimentology and paleogeography approaches have been widely applied in the coal accumulation regularity analysis. Since the 1990s, Chinese scholars have reconstructed the sequence-paleogeographic features of coal-bearing strata of different coal-accumulating periods and different coal-accumulating areas, which have laid a foundation for the prediction of coal resources. In the newest round of assessment of coal resource potentials completed in recent years, the paleogeography of the Carboniferous-Permian in the North China, the Late Permian in the South China, the Late Triassic in the South China, the Early-Middle Jurassic in the North China and Northwest China and the Early Cretaceous in the Northeast China have been reconstructed by sequence-paleogeographic method. The distribution of thick coal seams, representing the distribution of coal-rich belts, was analyzed from perspective of the sequence-paleogeography and with consideration of various tectono-sedimentary background, which provides theoretical support for the assessment and prediction of coal resource potentials in China.

The sequence stratigraphy approach can not only establish the isochronous stratigraphic framework for paleogeography reconstruction, but also provides an opportunity to reconsider the mechanism of coal accumulation in term of base-level cycles and accommodation space changes in different tectonic setting (Diessel 1992; Bohacs and Suter 1997; Li et al. 1996, 2001; Holz et al. 2002). The accumulating mechanisms of the thick coal seams can be well interpreted by the sequence stratigraphy (Shearer et al. 1994; Jerrett et al. 2011; Wang et al. 2016; Guo et al. 2018; Wang et al. 2020). Coal accumulation patterns and distribution of coal-accumulating centers in sequence stratigraphic framework provide a reliable guarantee for prediction of coal resources (Shao et al. 2009; Li et al. 2020). During undertaking the newest nation-wide assessment of coal resources, our group have studied the sequence stratigraphic framework, sequence-based paleogeography, and coal accumulation patterns of the coalbearing strata of each coal-accumulation periods in China.

This paper summarizes the research achievements on the sequence stratigraphy and coal accumulation of the major coal-accumulation periods, including the Late Carboniferous-Middle Permian in North China, the Late Permian in 
South China, the Late Triassic in South China, the Early and Middle Jurassic in North and Northwest China, and the Early Cretaceous in Northeast China.

\section{Coal-accumulating areas and coal-accumulating periods in China}

In the geological history, coal accumulation tends to take place in the vast areas which are often bounded by some major tectonic belts, and these areas are named "coal accumulating area" (CAA) (Han and Yang 1980; Han et al. 1996). The tectono-sedimentary background of the coal basins and the forming conditions of coal-bearing strata are similar to some extent in the same CAA.

In China, a total of 6 CAAs are subdivided based on their tectonic zonation, including the Northeast China, Northwest China, North China, South China, Yunnan-Tibet, and China offshore CAA, each of which contains unique coal-bearing strata of one or more ages (Fig. 1). The North China CAA is bounded by the Yinshan Mountains to the north and Helan Mountains to the west, and the Qinling-Dabie Mountains to the south, and includes eastern Ningxia, eastern Gansu, Shaanxi, Shanxi, Henan, Hebei,
Shandong, northern Jiangsu, northern Anhui, central and southern Inner Mongolia, Beijing, Tianjin and western Liaoning. The Northeast China CAA is bounded by the Yinshan Mountians to the south and includes eastern Inner Mongolia, Heilongjiang, Jilin and most part of Liaoning. The Northwest China CAA is bounded by the Helan Mountains to the east and the Kunlun Mountains to the south, and includes Xinjiang, northern part of Qinghai, and most parts of Ningxia and Gansu. The South China CAA is bounded by the Qinling-Dabie Mountains to the north, the Longmen Mountains and Ailao Mountains to the west, and includes eastern Yunnan, eastern Sichuan, Guizhou, Chonqing, Hubei, Hunan, Guangxi, Guangdong, Jiangxi, Fujian, Zhejiang, Shanghai, southern Jiangsu, and southern Anhui. The Yunnan-Tibet CAA is bounded by the Kunlun Mountains to the north and the Longmen Mountains and Ailao Mountains to the east, and includes Tibet, southern Qinghai, western Yunnan, and western Sichuan. The China offshore CAA includes the East China Sea Shelf Basin and South China Sea Basin, and also includes Taiwan and Hainan islands.

Coal-accumulating period, also known as coal-forming period, is a period when significant coal accumulations took place and coalfields of economic value were formed

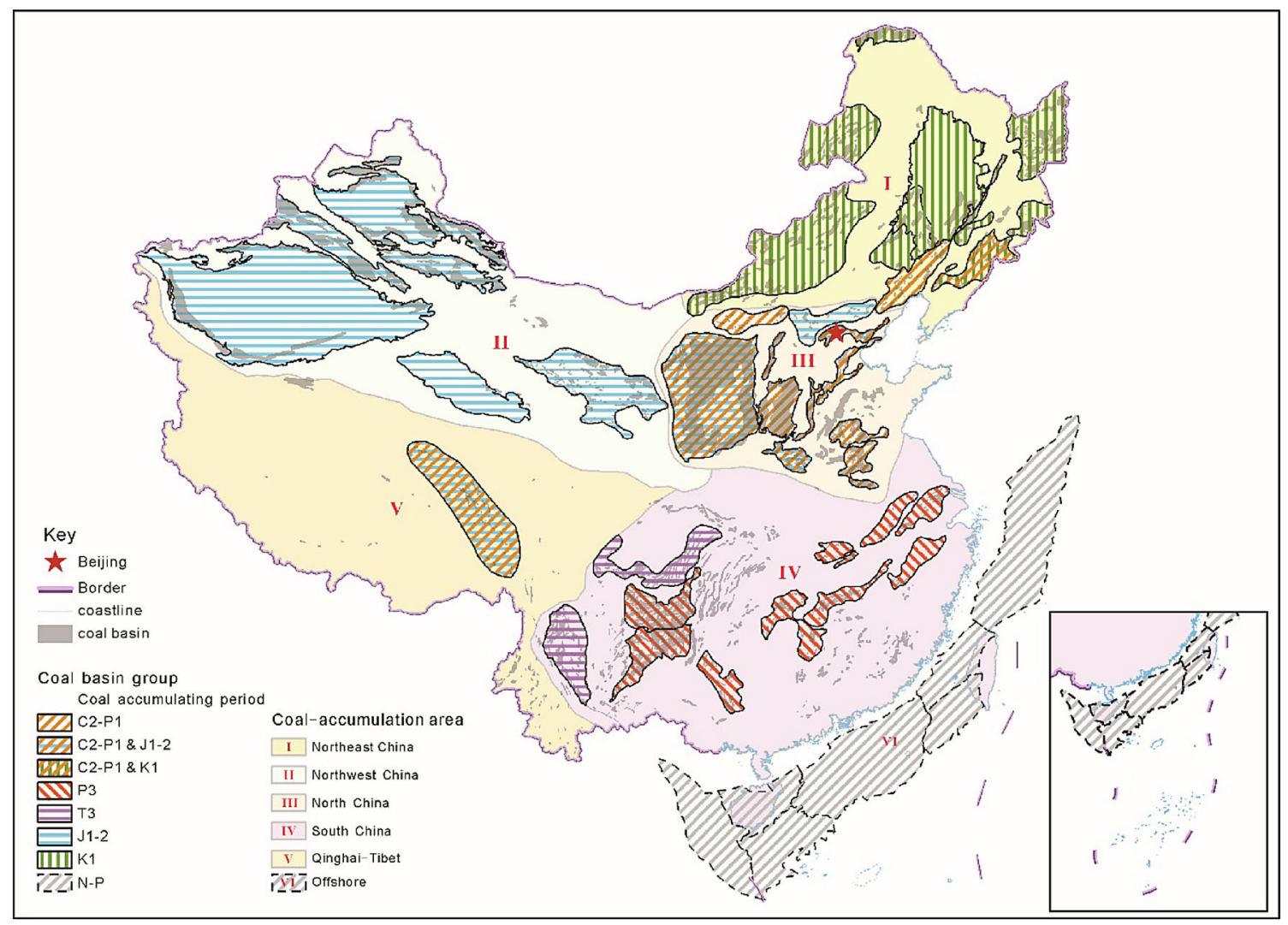

Fig. 1 Coal-accumulating areas in China (revised after Han and Yang 1980; Zhang 1995; Han 1996; Cheng 2001, 2016) 
(ECDES 2005). Coal accumulation in China can be traced back to the Neoproterozoic. From the Neoproterozoic to the Silurian, the sapropel coal with high ash content, also known as "stone coals", was formed, which contains the remains of bacteria, algae, and other lower plants. From Silurian to Middle Devonian, as the emergence of higher plants, the earliest humic coal was formed by the oldest terrestrial Psilophyte plants, and only from the Late Devonian did the coals of economic value start to accumulate (Han and Yang 1980).

From the perspective of coal deposits in the world, the intensity of coal accumulation increased from Late Devonian to Permian, and after a short "coal accumulation gap" in the Early and Middle Triassic, the intensity of coal accumulation increased from the Late Triassic through Jurassic, Cretaceous, and Tertiary (Paleogene and Neogene) (Fig. 2). As peat deposits are widely distributed in the world, the intensity of coal accumulation in the Quaternary is also high.

In China, main coal-accumulating periods are different among the different CAAs (Fig. 3). The main coal-accumulating periods in China include the Early Carboniferous in the South China CAA, the Late Carboniferous to Early Permian in the North China CAA, the Middle Permian in the South and North China CAA, the Late Permian in the South China CAA, the Late Triassic in the South China CAA, the Early and Middle Jurassic in the North and Northwest China CAAs, the Early Cretaceous in the Northeast China CAA, the Paleogene in the Northeast and South China CAAs, and the Neogene in the Northeast and South China CAAs. There are several discrete coal-accumulating periods in the Yunnan-Tibet CAA, including Early Carboniferous, Late Permian, Late Triassic, Early Cretacerous, and Tertiary (Paleogene-Neogene). The China offshore CAA was associated with the Paleogene-Neogene coal-accumulating periods. These coal-accumulating periods are consistent with the global coal-accumulating ages (Fig. 2). Among them, the Late Carboniferous to Early Permian, Late Permian, Early and Middle Jurassic, and Early Cretaceous are four most important periods, and the coal resources formed in these periods accounted for more than $98 \%$ of China's total coal resources (Cheng et al. 2001).

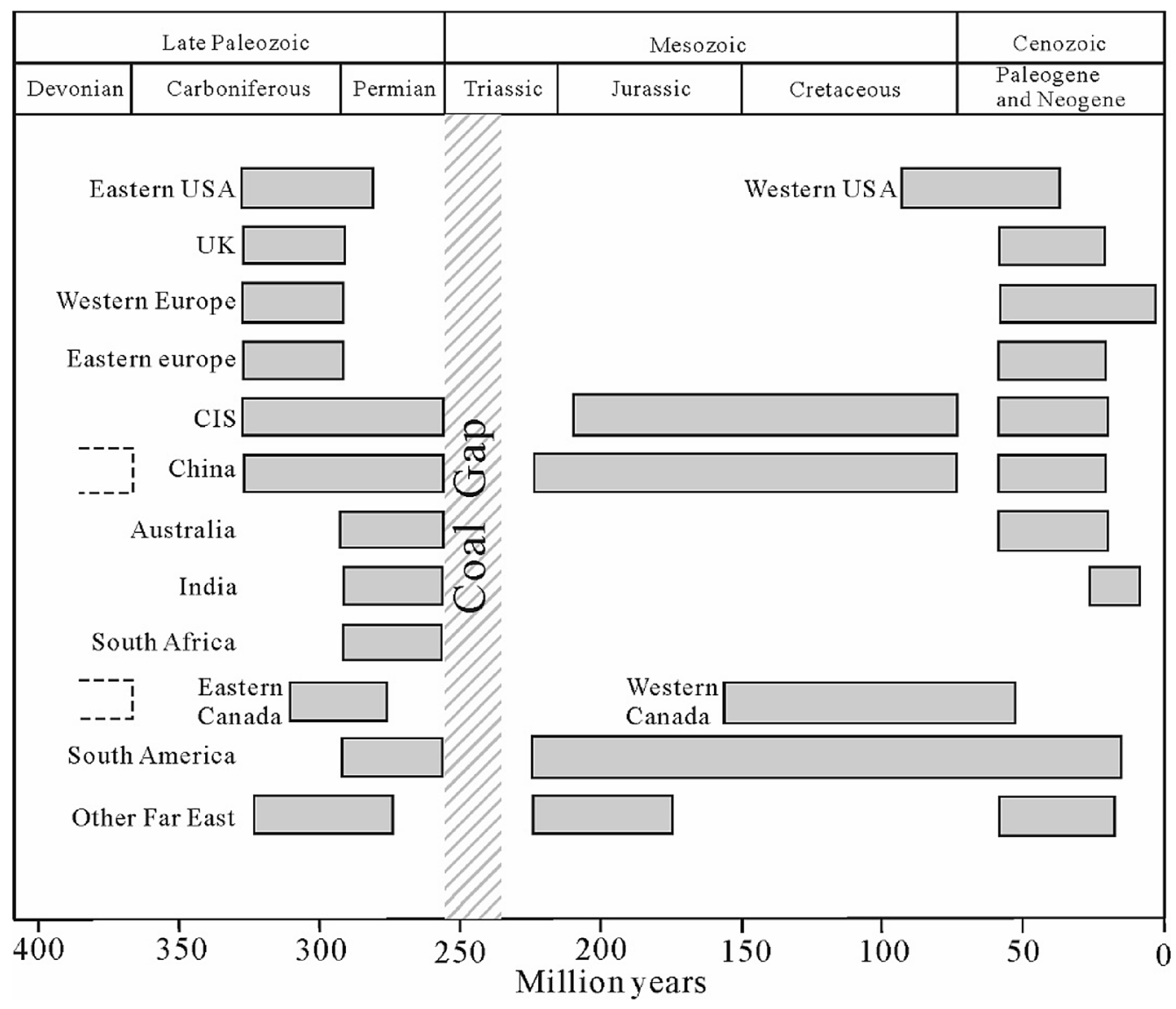

Fig. 2 Distribution of coal deposits of the different ages in the world. Modified after Thomas (2002) 


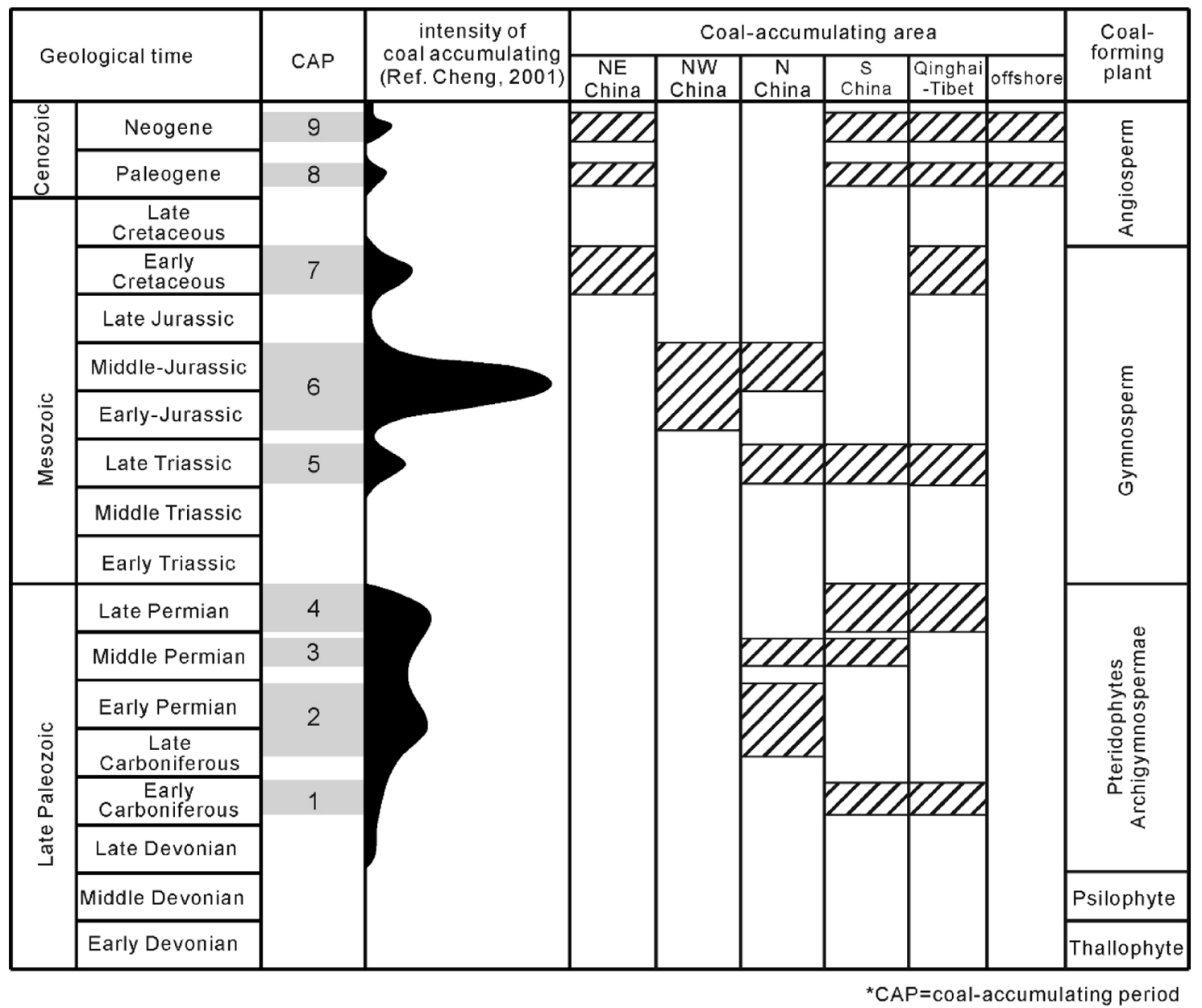

Fig. 3 The main coal-accumulating periods in China (revised after Han and Yang 1980; Zhang 1995; Cheng 2001; Qin 2017)

\section{Methods}

\subsection{Establishing of sequence stratigraphic framework}

For the purposes of regional stratigraphic correlation and paleogeographic mapping, the third-order sequence stratigraphic framework is established by using a time-based sequence stratigraphic methodology. A sequence is a genetically related succession of strata with no internal unconformities, bounded by unconformities and their correlative conformities (Mitchum et al. 1977; Catuneanu 2006). A complete sequence consists of the lowstand systems tract (LST), transgressive systems tract (TST), and highstand systems tract (HST) (Van Wagoner et al. 1988, 1990). The LST consists of the succession from sequence boundary (the onset of base-level rise) to the transgression surface (initial flooding surface). The TST is defined by the transgressive surface at its base to the maximum flooding surface on the top. The HST is composed of a succession from the maximum flooding surface to the upper sequence boundary.

\subsection{Compiling of paleogeography maps}

The database for compiling of paleogeography maps in our study consists of a number of full-hole coring borehole sections and outcrop sections which covers most of the study area. The contour maps for paleogeographical anlysis include isopachs of strata, sandstone and conglomerate thickness, sandstone and conglomerate percentages, conglomerate percentages, coarse/fine ratio (thickness of sandstone and conglomerate/thickness of siltstone and mudstone), marine limestone thickness and/or numbers of marine limestones beds, mudstone thickness, and coal seam thickness (Liu et al. 1991; Zhang et al. 1993, 1997; Feng et al. 2004, 2014; Shao et al. 2013b, 2014a, b). The subdivision of paleogeographic units were mainly based on the coarse/fine ratio contours and constrained by the other lithofacies parameters (e.g. contours of the sandstone and conglomerate thickness and the mudstone thickness), as 
Table 1 Lithological parameters of the contour maps for the reconstruction of paleogeography

\begin{tabular}{|c|c|c|c|}
\hline No. & Parameter & Statistic methods & Implication for paleogeography analysis \\
\hline 1 & Isopaches & Total thickness of the strata & $\begin{array}{l}\text { Indicating the regional subsidence and outline of the } \\
\text { sedimentary basin, and in most cases, reflecting the } \\
\text { paleo-slope and depositional centers in relation to the } \\
\text { direction of sediment supply }\end{array}$ \\
\hline 2 & $\begin{array}{l}\text { Contours of } \\
\text { conglomerate } \\
\text { thickness }\end{array}$ & Total thickness of conglomerate & $\begin{array}{l}\text { Indicating the possible direction of the provenance, and } \\
\text { also distribution of the conglomerate body }\end{array}$ \\
\hline 3 & $\begin{array}{l}\text { Contours of sandstone } \\
\text { thickness }\end{array}$ & Total thickness of sandstones & $\begin{array}{l}\text { Indicating the enrichment areas of the sandstone body, } \\
\text { distribution of the sandy channel or sand bar, } \\
\text { paleocurrent direction, and possible provenance } \\
\text { direction, and sometimes reflecting the range of the } \\
\text { delta sand body }\end{array}$ \\
\hline 4 & $\begin{array}{l}\text { Contours of mudstone } \\
\text { thickness }\end{array}$ & $\begin{array}{l}\text { Total thickness of the mudstones including siltstone, } \\
\text { mudstone, claystone }\end{array}$ & $\begin{array}{l}\text { Indicating the distribution of the low energy } \\
\text { environments such as flood basin, interdistributary bay, } \\
\text { tidal flat, and sublittoral and profundal lake }\end{array}$ \\
\hline 5 & $\begin{array}{l}\text { Contours of carbonate } \\
\text { rock thickness }\end{array}$ & $\begin{array}{l}\text { Total thickness of carbonate rocks including } \\
\text { limestone, siliceous limestone, and muddy } \\
\text { limestone, and the chert are often counted }\end{array}$ & $\begin{array}{l}\text { Indicating the range of the marine transgression, and } \\
\text { landward distribution of the delta, and range of the } \\
\text { carbonate platform }\end{array}$ \\
\hline 6 & $\begin{array}{l}\text { Contours of coal } \\
\text { thickness }\end{array}$ & Total coal thickness & $\begin{array}{l}\text { Indicating the distribution of the coal-accumulating belts } \\
\text { and coal-accumulating centers, and reflecting the } \\
\text { distribution of the swamp environment }\end{array}$ \\
\hline 7 & $\begin{array}{l}\text { Contours of the } \\
\text { Sandstone to } \\
\text { mudstone thickness } \\
\text { ratios }\end{array}$ & $\begin{array}{l}\text { Sandstone (also include conglomerate) to mudstone } \\
\text { (also include siltstone) thickness ratios }\end{array}$ & $\begin{array}{l}\text { Indicating the distribution of the high-energy } \\
\text { environments such as fluvial channel, distributary } \\
\text { channel, barrier bar, littoral lake, and these contours } \\
\text { constitute the major parameter for facies zonation }\end{array}$ \\
\hline
\end{tabular}

seen in Table 1. The time intervals used for the paleogeographical reconstruction were corresponding to the third-order sequences. This quantitative paleogeographic mapping can objectively reflect the distribution of regional sedimentary facies, tectonic configuration, coal accumulation patterns under the isochronous stratigraphic framework, thus the paleogeographic map can better serve for the prediction of coal resources.

\section{Sequence-paleogeography and coal accumulation of the Carboniferous-Permian in the North China CAA}

\subsection{Sequence stratigraphic framework of the Carboniferous-Permian coal-bearing strata}

The sequence boundaries were represented by regional unconformity, transgression direction switching surface (Shang 1997), the base of incised valley fill sandstone, facies-reversal surface and associated paleosols. According to these sequence boundaries, the coal-bearing strata were subdivided into 2 second-order tectonic sequences and 7 third-order sequences (Fig. 4) (Shao et al. 2014a).
The first second-order tectonic sequence contains 2 third-order sequences SQ1 and SQ2. The base of SQ1 is marked by the unconformity between the underlying Middle Ordovician (Majiagou or Fengfeng Formation) and the overlying Upper Carboniferous (Benxi Formation), and the top boundary of SQ1 is marked by the paleosol horizon beneath a regionally correlatable coal seam including the No. 9 coal seam in the Taiyuan Xishan coalfield, the No. 1 coal seam in the Henan area, and the No. 17 coal seam in the Shandong area. The age range of SQ1 is from the Bashkirian stage to the Gzhelian stage of the Late Carboniferous. SQ2 is from the top boundary of SQ1, representing a switching surface of transgression direction (Shang 1997), to the base of the Shanxi Formation, and the age range is from the Asselian stage to the Artinskian stage of the Early Permian.

The second second-order tectonic sequence contains 5 third-order sequences from SQ3 to SQ7. SQ3 is equivalent to the regional Shanxi Formation. The bottom boundary of SQ3 is marked by the erosional bases of the fluvial-channel or distributary-channel sandstones (regionally called "Beichagou Sandstones"), and the top boundary is represented by the erosional bases of a regionally-correlatable sandstone formations ("Luotuobozi Sandstones") of the Xiashihezi Formaiton. The age range is roughly 
corresponding to the Kungurian stage. SQ4 is equivalent to the Xiashihezi Formation and spans from the base of the Luotuobozi Sandstones to the top of the Taohua Mudstone (a regionally correlatable reddish mottled mudstone). The age range of SQ4 is from the late Kungurian to the early Wordian. SQ5 is equivalent to the lower part of the Shangshihezi Formation, spanning from the bottom of this formation to the base of a thick-bedded sandstones in the lower middle part of the formation (e.g. the K7 Sandstones in the Taiyuan Xishan coalfield), and the age range is equivalent to the Capitanian of the late Middle Permian. SQ6 is equivalent to the middle-upper part of the Shangshihezi Formation, and is confined at its base by a thick-bedded sandstone and at its top by the bottom of the Shiqianfeng Formation (or Sunjiagou Formation), and the age range is within the Wuchiapingian stage. SQ7 is equivalent to the Shiqianfeng Formation (or Sunjiagou Formation), and its top is corresponding to the PermianTriassic boundary. The age range of SQ7 is equivalent to the Changhsingian stage.

\subsection{Paleogeography and coal accumulation of the Carboniferous-Permian in the North China CAA}

The lihtofaies paleogeography maps of each third-order sequence was based on the contours of a variety of lithofacies parameters, including strata thickness, coarse/fine ratio, limestone percentages, and coal thickness. The comparison of the contours of coal thickness with the distribution of facies units of the lithofacies paleogeography has revealed that the favorable coal-accumulating environments were delta, fluvial plain, and lagoon-tidal flat (Liu et al. 1987; Shao et al. 2014a).

During SQ1 period, the North China CAA was developed with tidal flat-lagoonal facies, and the coal accumulation intensity was relatively weak, and the major coals were developed in the Weibei coalfield. During SQ2 period, coal-accumulating environments in the North China CAA were mainly delta and tidal flat-lagoon (Fig. 5). During SQ3 period, coal-accumulating environment was mainly delta (Fig. 6). For these three sequences, coal accumulation intensity was stronger in SQ2 (middle and upper Taiyuan Formation) and SQ3 (Shanxi Formation) with the coal accumulating centers being distributed in the Jungar, Datong, Shuozhou, Wuhai, Fengfeng areas, and the Beijing-Tianjin-Tangshan area. During SQ4 and SQ5 periods, with seawater retreating southward, the coal-accumulating delta environment was also migrating to the south. Coal accumulation in SQ4 (Xiashihezi Formation) and SQ5 (first member of the Shangshihezi Formation) was weak and the coal-accumulating centers were distributed in the southern part of the North China CAA, including
Pingdingshan, Huainan, and Huaibei coalfields. During SQ6 and SQ7 periods, the North China CAA was dominated by the fluvial and lacustrine facies and the coal accumulation was impeded by an arid climate during these periods.

\section{Sequence stratigraphic framework and coal accumulation pattern of the Late Permian in the South China CAA}

\subsection{Sequence stratigraphic framework of the Late Permian coal-bearing strata}

The Late Permian is the major coal-accumulating period in South China CAA. The Late Permian coal-bearing strata include Xuanwei, Longtan, Wujiaping, Heshan, Cuipingshan, Wulinshan, Wangjiazhai and Changxing Formations, in which the Xuanwei, Longtan, Wujiaping, Wangjiazhai and Changxing Formations are the most important coalbearing strata (Fig. 7) (Wang 1996b; Li 1999). A number of scholars have studied the sequence stratigraphy of the Late Permian in the South China CAA, such as Wang et al. (1999) and Wang (2001) who subdivided the Late Permian into five third-order sequences. In our study, according to the distribution of the regional-correlative marine limestone markers in the cratonic basin, such as the case in western Guizhou (Fig. 8), three transgressive-regressive cyclic sequences were clearly recongnized (Shao et al. 1993, 2013a, b). In addition, based on the recognized sequence boundaries and regional stratigraphic correlations of the outcrop and borehole sections, the Late Permian in south China is subdivided into 3 third-order sequences, namely SQ1, SQ2, and SQ3 in ascending order.

\subsection{Paleogeography and coal accumulation of the Late Permian in the South China CAA}

According to the differences of tectonic setting, the coalbearing strata and sedimentary features, the South China CAA is subdivided into two coal-bearing sedimentary area, Yangtze region and Southeastern region. The distribution and evolution of the lithofacies paleogeography of each third-order sequence in the South China CAA is discussed below.

\subsubsection{Lithofacies paleogeography of $S Q 1$}

During SQ1 period, the gravelly siliciclastics were mainly distributed along the eastern side of the Kangdian Oldland and the sedimentary environments were mainly alluvial fan-fluvial plain. From the east side of Kangdian Oldland eastward to the Upper Yangtze basin, the sedimentary 


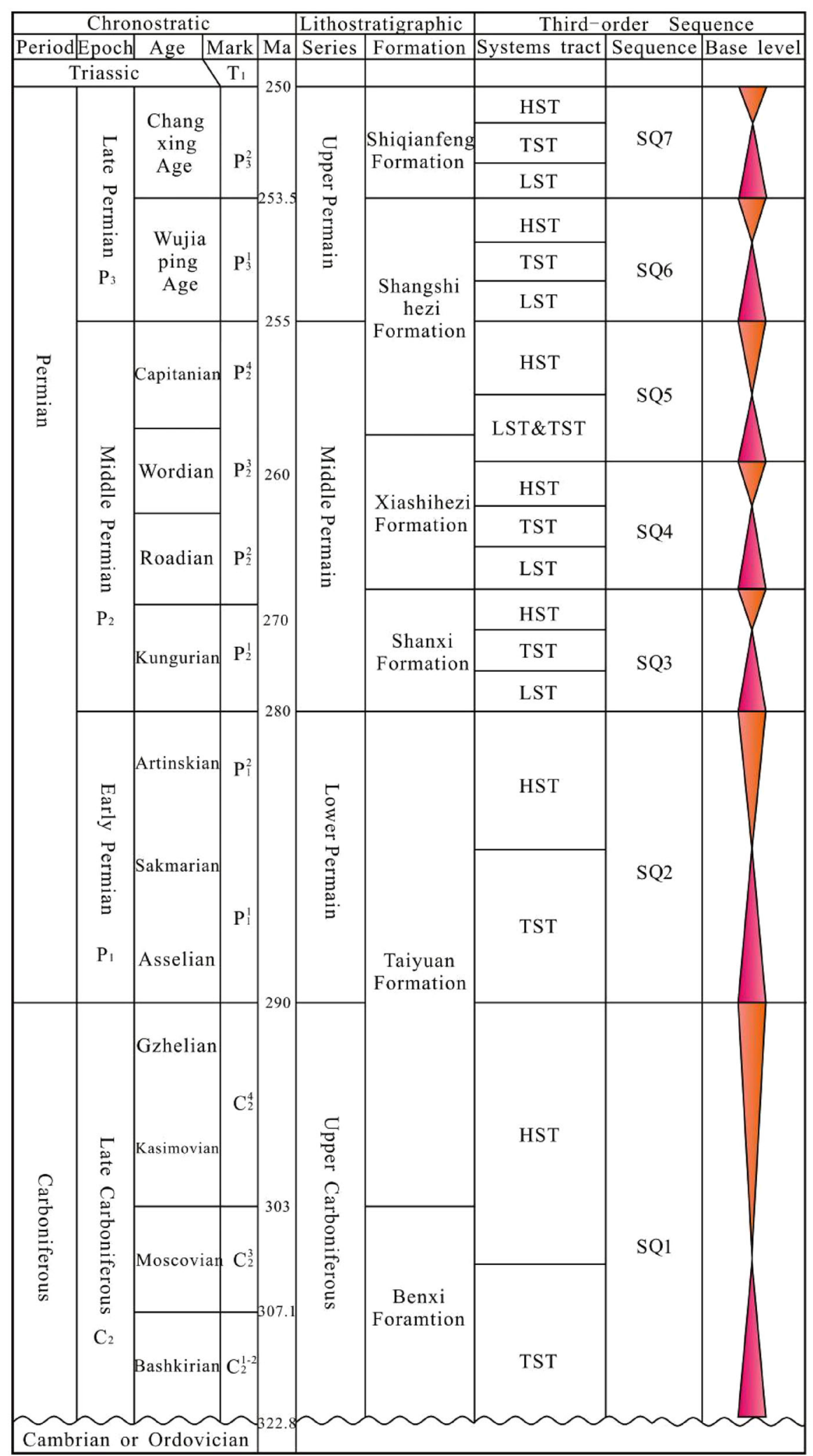

Fig. 4 Sequence stratigraphic framework of the Carboniferous-Permian coal-bearing strata in the North China coal-accumulating area (revised after Shao et al. 2014a) 


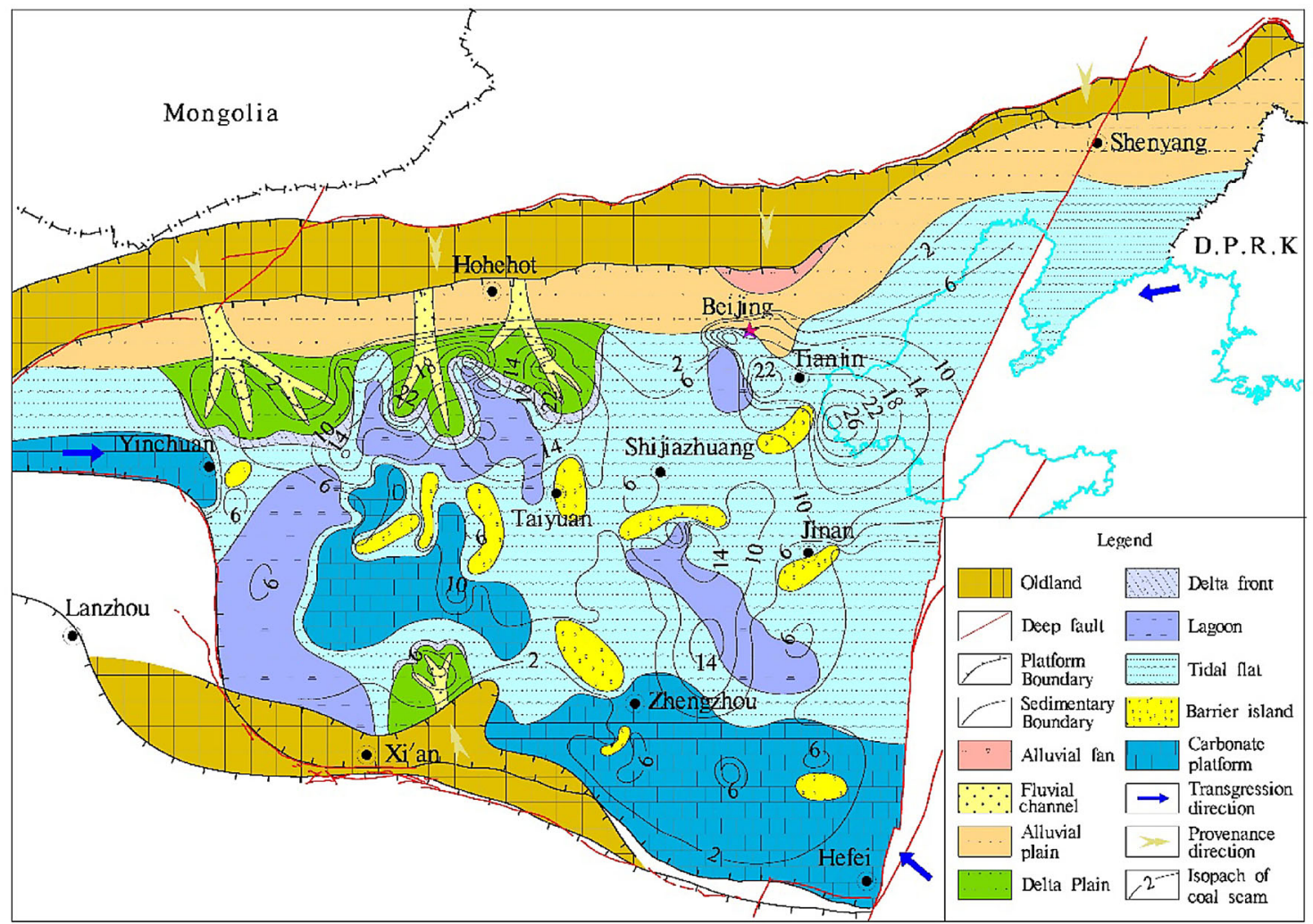

Fig. 5 Sequence-paleogeography and coal-accumulating regularities of SQ2 (most part of Taiyuan Formation) in the North China CAA

facies can be categorized into 5 different types, including alluvial fan, braided river, delta, tidal flat and carbonate platform (Shao et al. 2013b). Organic reefs were mainly developed in the southern Guizhou and northwestern Guangxi, and were composed of sponge bafflestone and framestone. Fluvial-lacustrine facies were developed along the western margin of the Cathaysia Oldland and the southeastern margin of the Wuyi Oldland. The tidal-flat facies were developed around the Wuyi Oldland, Yunkai Oldland and Jiangnan Oldland. Due to abundant supply of terrigenous clastics, the delta facies were developed in the southwestern margin of the Wuyi Oldland and the northwestern margin of the Yunkai Oldland, whereas no delta was developed in the northwestern margin of the Wuyi Oldland.

The thickness of coal seams in SQ1 ranges from 0 to $19.41 \mathrm{~m}$, with coal seams thicker than $5 \mathrm{~m}$ being developed in eastern Yunnan and western Guizhou, the Huatang coal mine of Hunan, the Suzhou area of Jiangsu, and the Shahu area of Guangdong. The thickest coals were distributed in the Enhong coal mine of eastern Yunnan, and the total thickness is $19.41 \mathrm{~m}$. The coal were mainly accumulated in the tidal-influenced lower delta plain and lagoon-tidal flat environments.

\subsubsection{Lithofacies paleogeography of $S Q 2$}

During SQ2 period, a total of 5 oldlands were developed in the South China CAA, including the Kangdian Oldland, Cathaysia Oldland, Jiangnan Oldland, Wuyi Oldland and Yunkai Oldland (Fig. 9). The marine transgression was generally from the southwest. To the eastern margin of the Kangdian Oldland, such as eastern Yunnan, western Guizhou and southern Sichuan, the sedimentary pattern is similar to that of SQ1, that are the alluvial fan, braided river, delta, tidal flat, and carbonate platform distributed eastward from the source area (Shao et al. 2013b). To the western margin of the Cathaysian Oldland and the southeastern margin of the Wuyi Oldland, due to abundant supply of siliciclastics, the meandering river and lacustrine sediment were developed ( $\mathrm{Li}$ 1999). The area of the Jiangnan Oldland decreased at this time. All other regions in the South China CAA were experiencing influence of marine transgression. In the area around the Jiangnan Oldland, the previously developed delta environment was replaced by the shallow marine environment.

In SQ2, the total thickness of coal seams ranges from 0 to $20 \mathrm{~m}$ (Fig. 9), which is greater than those of SQ1. The area with the coal thickness greater than $10 \mathrm{~m}$ was mainly developed in the Enhong coal mine of eastern Yunnan, and the Zhijin-Nayong coalfield and Shuicheng region in 


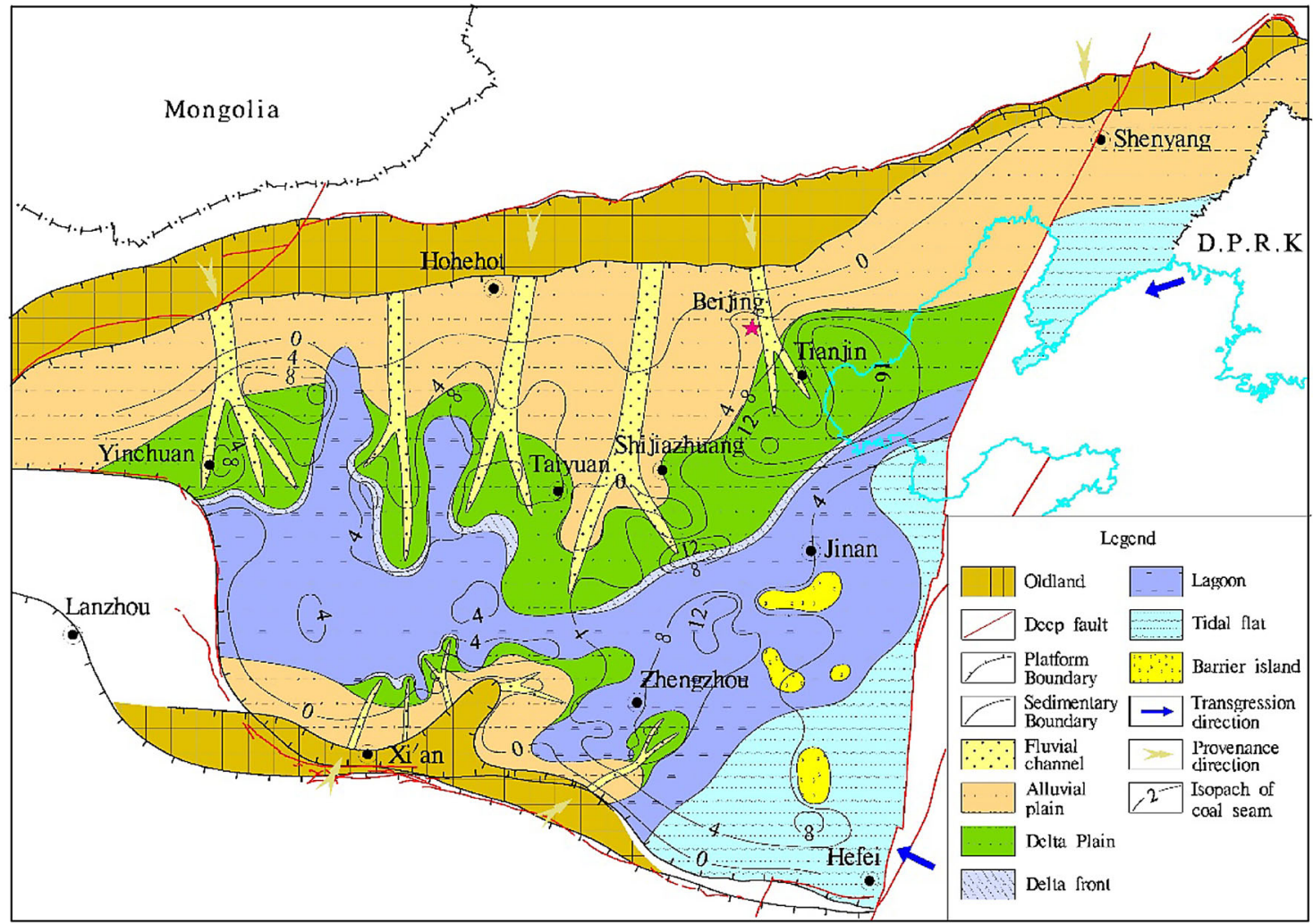

Fig. 6 Sequence-paleogeography and coal-accmmulating regularities of SQ3 (Shanxi Formation) in the North China CAA

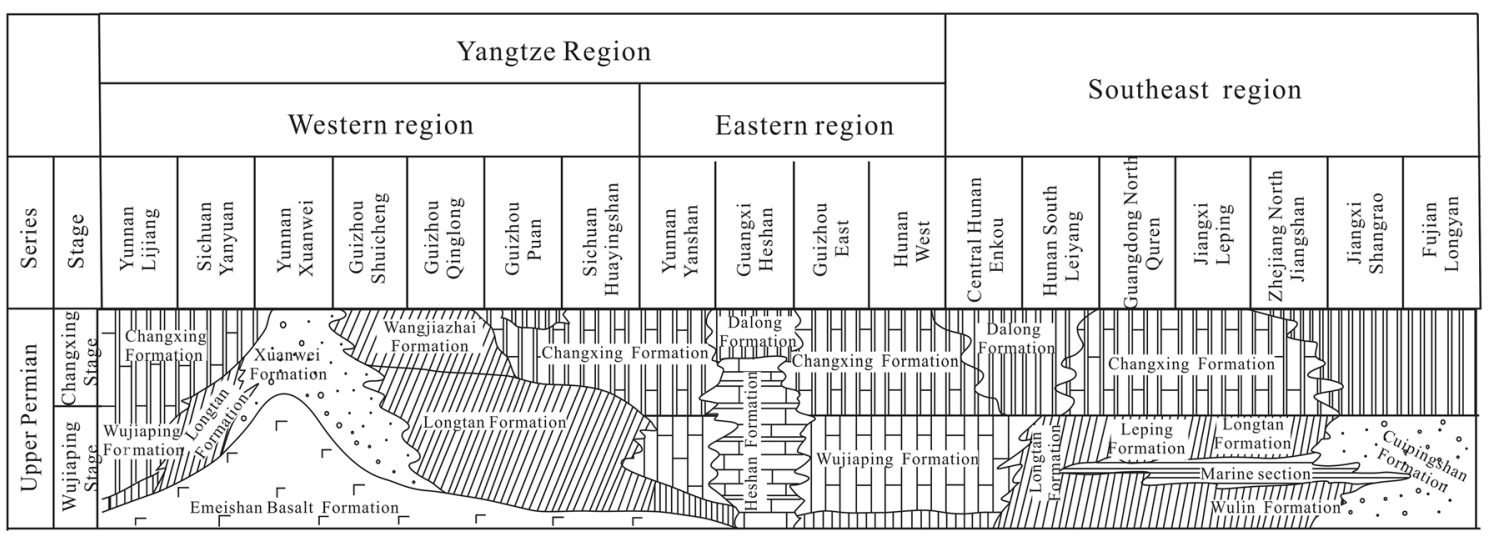

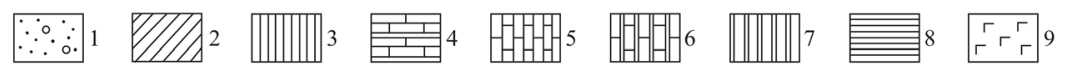

1.Continental coal-bearing strata 2.Paralic coal-bearing strata 3.Coastal marsh facies of coal-bearing strata 4.Marine coal-bearing strata 5.limestone 6.Siliceous limestone 7.Siliceous rock、 Siliceous shale 8.Shale 9.Basalt

Fig. 7 Subcorrelation and depositional types of the lithological formations of the Late Permian in the South China CAA (revised after Zhang, 1995; Shao et al. 2016)

western Guizhou. Besides, the coals in the Xujiazhuang, and Housuo coal mines of eastern Yunnan are also thicker than $7 \mathrm{~m}$. During this period, the coal-accumulating centers were developed in an area covering eastern Yunnan, western Guizhou, Chongqing and southern Sichuan. The coal-accumulating center also includes the southeast of Hunan where the coal seams are thicker than $5 \mathrm{~m}$. Meanwhile, an emerging coal-accumulating center was 


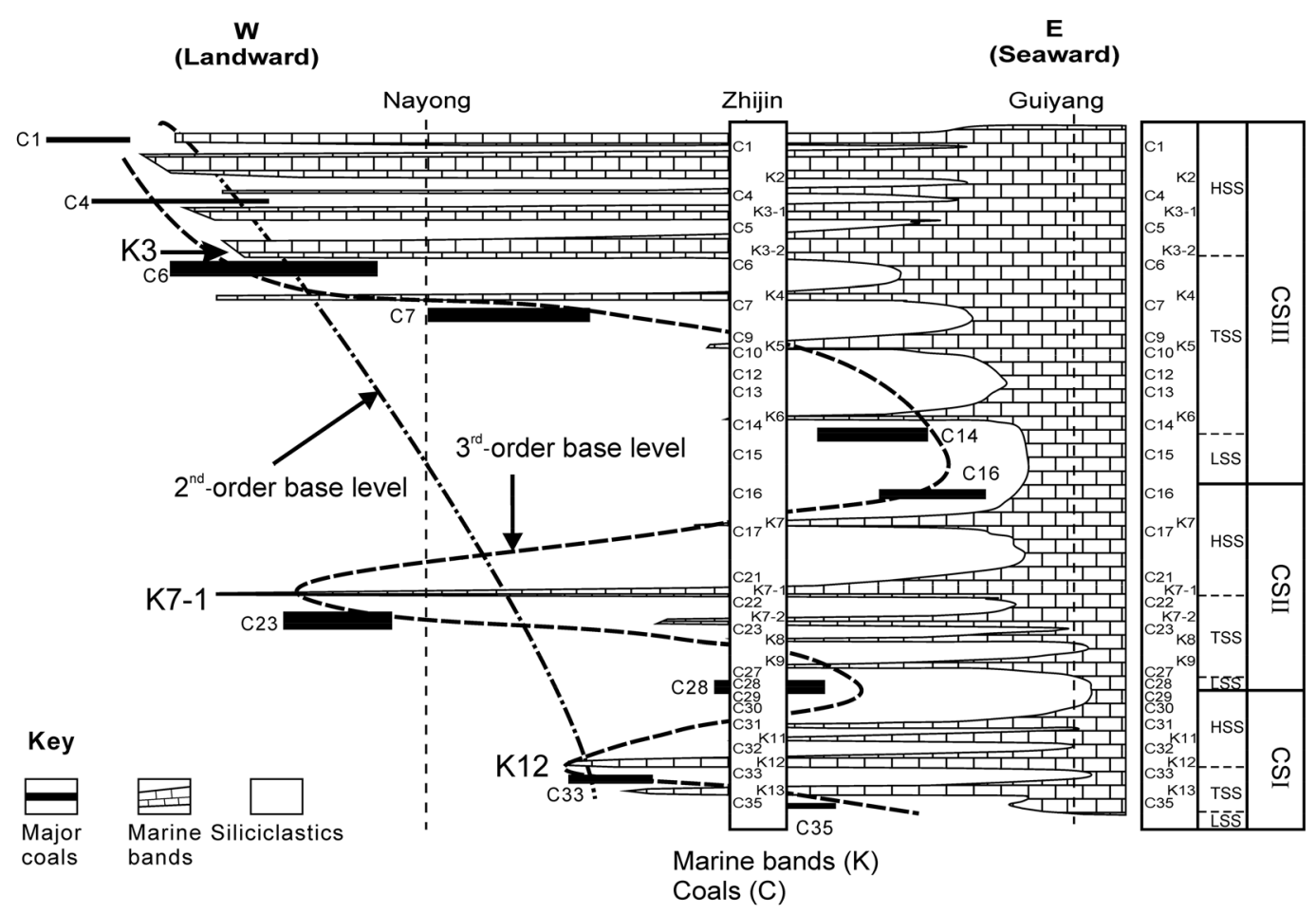

Fig. 8 Aerial extent of marine bands (limestone and fossiliferous mudstone beds) in SW China that can be used to define the 4th order marine transgressions, showing interpolated 2nd- and 3rd-order sequences; the distribution of major coals in this area are also schematically presented. Revised from Shao et al. (1993, 2013a, b) and Wang et al. (2011)

developed in Qujiang and Longnan of Jiangxi Province where approximately $7 \mathrm{~m}$ thick coal seams were developed. The coal seams in this sequence were mainly accumulated in the delta plain environment and the thickness of coal seams gradually decreases from west to east in the South China CAA.

\subsubsection{Lithofacies paleogeography of SQ3}

During SQ3 period, a large-scale transgression had significantly narrowed the range of the oldlands. The Jiangnan Oldland and Wuyi Oldland disappeared, and only the Kangdian Oldland, Yunkai Oldland and Cathaysian Oldland still existed. The Wuyi and Jiangnan Oldlands were covered by marine environments and became a subaqueous uplift. The marine transgression mainly came from the southwestern area. To the eastern side of the Kangdian Oldland, the coastline had migrated westward to the line of Renshou-Luzhou-Xingwen of Sichuan, and the line of Hezhang-Shuicheng-Panxian in Guizhou. In these areas, the alluvial fan, fluvial plain, delta and lacustrine facies were developed, but the distribution range of the meandering river and lacustrine facies were relatively narrower and the area of delta faceis were clearly reduced. In western Guizhou and eastern part of southern Sichuan, previously developed deltas were replaced by tidal flat and lagoon environments. Coal seams were accumulated in these tidal flat and lagoon environments but their thickness varies laterally (Shao et al. 2013b, 2016). At the same time, the other parts of the Yangtze Region and the southeastern Region were occupied by coastal and shallow marine environments, and the coal accumulation was terminated due to marine transgression.

The total thickness of coals in SQ3 ranges from 0 to $28.27 \mathrm{~m}$. During this period, the coal seams were relatively thicker and the coal-forming regions were more concentrated. The areas with the total coals thickness greater than $10 \mathrm{~m}$ were mainly restricted in eastern Yunnan and western border of Guizhou. The coal-accumulating centers were located in the Xuanwei-Fuyuan coalfield of eastern Yunnan and the Liupanshui coalfield of western Guizhou. The coal accumulation gradually became weaker in most parts of Chongqing, eastern part of southern Sichuan, and eastern part of western Guizhou, where the coal-accumulating centers were previously developed in SQ2. Meanwhile, the thickness of coal seams in southern Hunan was less than $1 \mathrm{~m}$, and no coal was developed in other areas of the South China CAA during this period. Therefore, the coals were mainly formed in delta plain environments in the western part of the South China CAA and the thickness gradually decreased from west to east (Shao et al. 2016). 


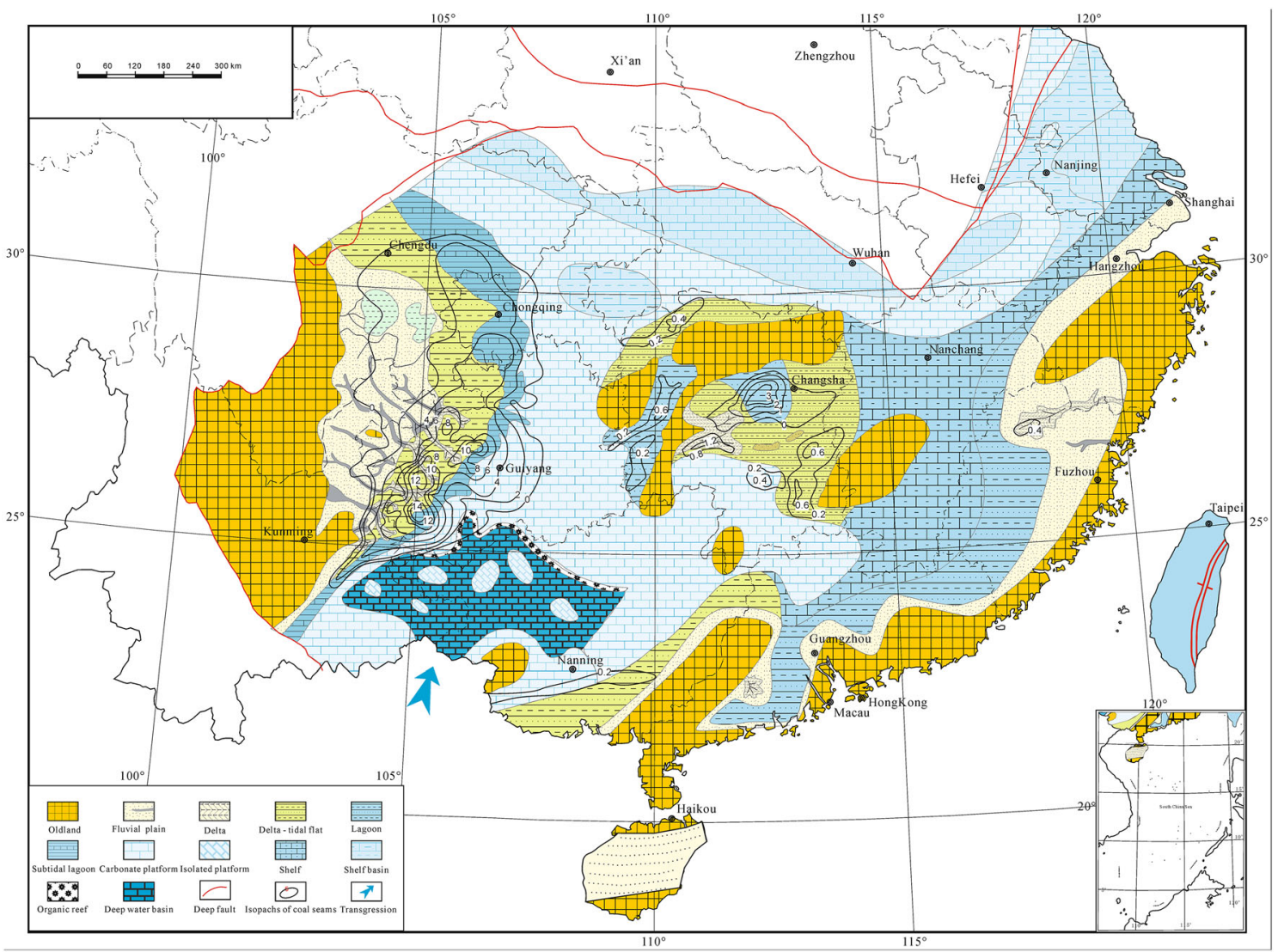

Fig. 9 Paleogeography and distribution of coal seams of SQ2 of the Late Permian coal-bearing strata in the South China CAA

Generally, throughout the Late Permian, the coal-accumulating centers of SQ1 spread all over the South China CAA, but the thicker coals were only distributed in the eastern side of the Kangdian Oldland, and the area surrounded by the Jiangnan, Wuyi and Cathaysia/Cathaysian Oldlands. In SQ2, the coal-accumulating centers were located to the eastern side of Kangdian Oldland and the central South China CAA, including Yunnan, Guizhou, Sichuan, central-southern Hunan and central-southern Jiangxi. In the northern Zhejiang, southern Jiangsu and northern Guangdong, few or no coals were formed in this period. Coal accumulation in the South China CAA during SQ3 period was only confined to the eastern margin of the Kangdian Oldland, including eastern Yunnan, western Guizhou, and the western part of southern Sichuan.

\section{Sequence-paleogeography and coal accumulation of the Late Triassic coal-bearing strata in the South China CAA}

The Late Triassic coal-bearing strata are widely developed in the South China CAA, including the Xujiahe Formation in Sichuan, the Daqiaodi Formation in Yunnan and
Sichuan, the Luojiadashan Formation in Yunnan, the Huobachong Formation in Guizhou and Yunnan, the Hongweikeng and Toumuchong Formations in Guangdong, the Chutanlong and Yangmeilong Formations in southeast Hunan, the Zijiachong, Sanjiachong and Sanqiutian Formations (Anyuan Group) in eastern Hunan and central and western Jiangxi, the lower Jiaokeng Formation in Fujian (Fig. 10). These coal-bearing strata are developed with 2 depositional types including continental and transitional. The continental coal-bearing strata were mainly developed in the upper Yangtze area, mainly in Sichuan Basin, while the transitional coal-bearing strata were mainly developed in the Hunan-Jiangxi-Guangdong area in central south of South China CAA. Besides, some small lacustrine and intermontane basins were scattered elsewhere in the South China CAA (Shao et al. 2014b).

\subsection{Sequence stratigraphy of the Late Triassic coal- bearing strata}

The Late Triassic coal-bearing strata were subdivided into 5 sequences based on sequence boundaries such as regional unconformities and tectonic stress switching surfaces, fluvial incision surfaces, and abrupt changing surfaces of 
litholofacies (Fig. 10). Each sequence was subdivided into LST, TST and HST. The Late Triassic lasted about $36 \mathrm{Ma}$, from 237 to $201.3 \mathrm{Ma}$ (ICS 2018), thus each sequence lasted about $7 \mathrm{Ma}$, roughly corresponding to the third-order sequence of Vail et al. (1977).

\subsection{Paleogeography and coal accumulation of the Late Triassic in the South China CAA}

The paleogeographic configuration of the Late Triassic in the South China CAA was mainly continental lacustrine Sichuan Basin, the residual marine basin of southwestern Guizhou and western Yunnan, the Hunan-Jiangxi-Guangdong bay basin, the intermontane basins and continental lacustrine basins scattered in Jiangnan Oldland. The provenance of these basins were mainly from the adjacent uplifed areas, including Longmen Mountains, MicangDaba Mountains, Kangdian Oldland and Jiangnan Oldland (Fig. 11). Two major facies types, including continental and transitional, were identified within the coal-bearing strata based on characteristics of lithofacies and facies associations (Shao et al. 2014b). The continental facies types include alluvial fan, braided fluvial and meandering fluvial facies, and the transitional facies types include delta, lacustrine (mainly sublittoral lake), tidal flat-lagoon, coastal plain and bay facies. The continental facies were mainly distributed in the upper Yangtze Block area, typically in the Sichuan Basin, whereas the transitional facies were mainly distributed in the eastern part of the South China CAA, typically in the Hunan-Jiangxi-Guangdong littoral and shallow marine area.

The most favorable coal-accumulating paleogeographic unit was the delta plain, followed by fluvial plain, and tidal flat-lagoon. It was considered that the coal-accumulating centers were distributed in the Leshan-Weiyuan coalfield and the Huayingshan coalfield of the Sichuan Basin, and the southeastern Hunan and western central Jiangxi in the Hunan-Jiangxi-Guangdong coastal and shallow marine area.

The Sichuan Basin was a typical non-marine basin located in the western part of the South China CAA, and the coal seams throughout the Late Triassic in this basin have a total thickness ranging between 1 and $10 \mathrm{~m}$, unevenly distributed in the different sequences. SQ1 and SQ2 were developed with the marine reef, tidal flat-lagoon, and no coal was accumulated. The major coal seams developed in SQ3 and SQ4 were mainly formed in interdistributary bay environments of delta plain. Some locally distributed minable coal seams were formed in the littoral lacustrine environments and the back swamp of fluvial environments. The coal-accumulating centers in the Sichuan Basin were mainly distributed in the piedmont area of the Longmen Mountains, the Guangyuan-
Wangcang area, the Dazhu-Huafu Mountain area, and the Leshan-Weiyuan area. In other parts of the western South China CAA, coal-accumulating centers were also developed in the Baoding Basin and the Binchuan-Xiangyun area (Fig. 11).

The coal-accumulating centers in eastern part of the South China CAA during the Late Triassic were mainly distributed in the coastal and shallow marine bay basin along the Hunan-Jiangxi-Guangdong, developed with the coastal-bay and tidal flat-lagoon environments (Shao et al. 2014b). The coal-rich units of coastal-bay environment were mainly distributed in central Jiangxi, central and southern Guangdong. The coal-rich units of tidal flat-lagoon environment were mostly distributed in northern Jiangxi, eastern Hunan, middle Guangdong and southern Fujian. The coal-accumulating intensity of the tidal flatlagoon-bay environment was the highest, and the minable coal seams were developed in a vast area with continuous areal distribution, with the total thickness ranging from 2 to $5 \mathrm{~m}$ and up to $10 \mathrm{~m}$. The coal-accumulating centers were distributed in the area from the southeastern Hunan to the western Jiangxi. The coal-accumulation intensity of coastal-bay environment came second, and the minable coal seams were developed in a large area with an intermittently continuous distribution, with the total thickness ranging from 2 to $4 \mathrm{~m}$. The coal-accumulating centers were mainly distributed in central Guangdong. In general, the coal-accumulating centers during the Late Triassic mainly include those in the Leping, Fengcheng, Liuyang-Pingxiang, Binzhou-Leiyang, central Guangdong, Zhangping and Longyan areas (Fig. 11).

\section{Sequence-paleogeography and coal accumulation of the Early and Middle Jurassic in the North and Northwest China CAAs}

\subsection{Sequence stratigraphy of the Early and Middle Jurassic coal-bearing strata}

The Early and Middle Jurassic coal-bearing strata were mainly developed in the North and Northwest China CAAs. The coal-bearing strata were subdivided into 5 third-order sequences (Fig. 12), in which SQ1 and SQ2 were developed in the Early Jurassic, and SQ3, SQ4 and SQ5 were developed in the Middle Jurassic. The duration of these sequences is roughly equivalent to Vail's thirdorder sequence (Vail et al. 1977). SQ1 corresponds to the Hettangian and Sinemurian stages of the Early Jurassic; SQ2 corresponds to the Pliensbachian and Toarcian stages of the Early Jurassic; SQ3 corresponds to the Aalenian and Bajocian stages of the Middle Jurassic; SQ4 corresponds to 


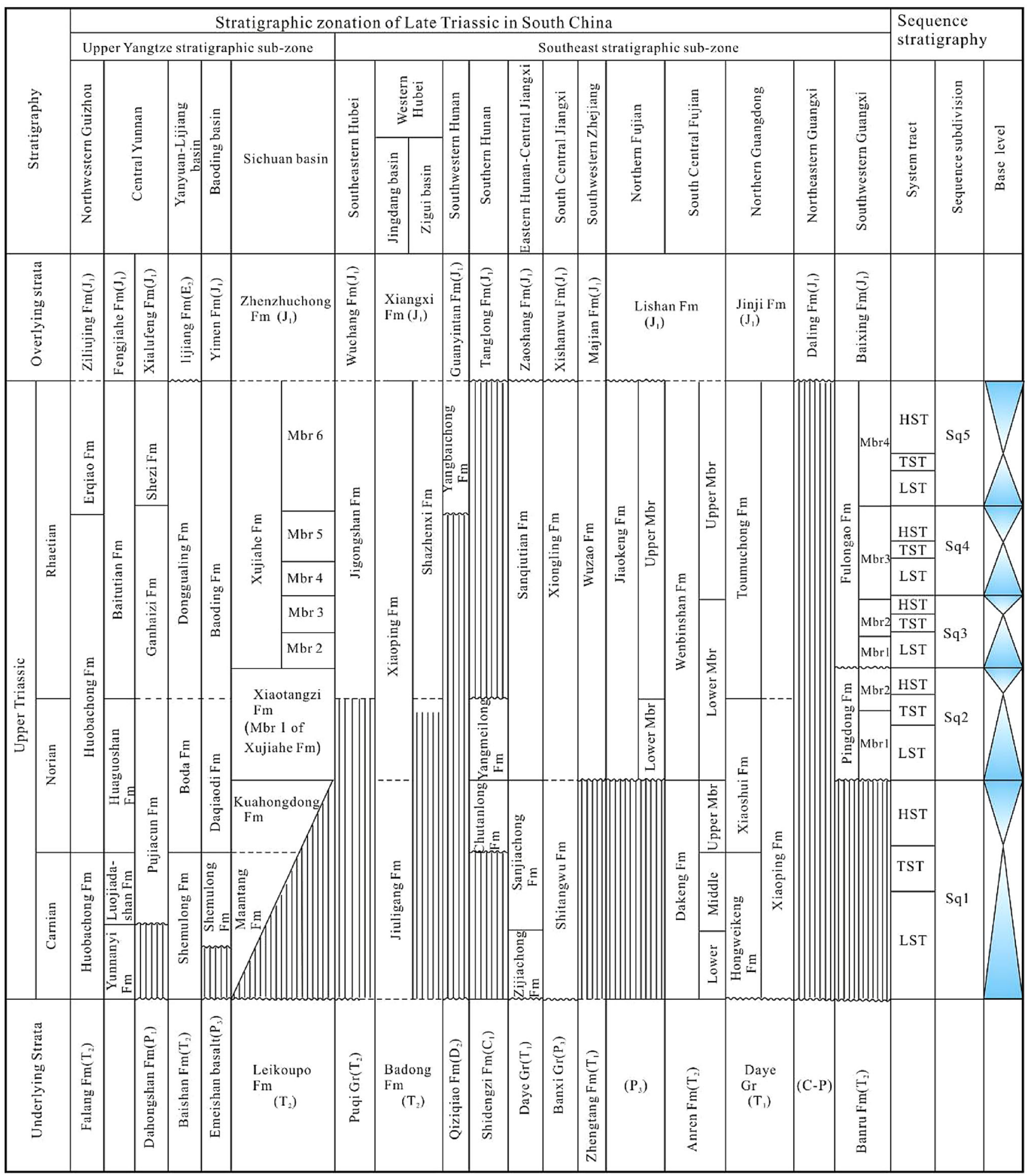

Fm-Formation; Mbr-Member; Gr-Group

Fig. 10 Lithostratigraphy and sequence stratigraphic framework of the Late Triassic coal-bearing strata in the South China CAA (revised after Shao et al. 2014b) 


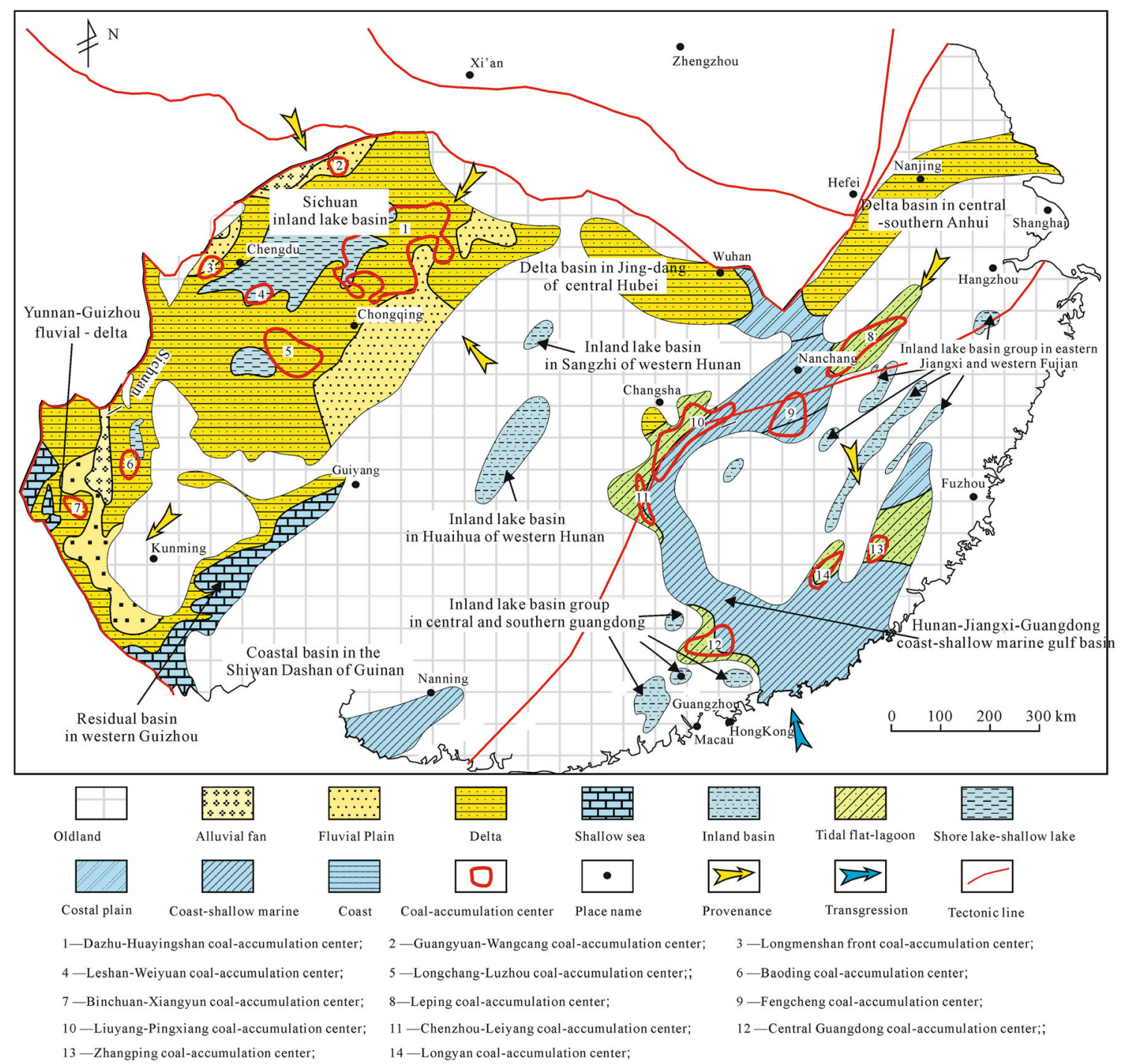

Fig. 11 Paleogeography and distribution of coal-accumulating centers of the Late Triassic in the South China CAA (modified after Shao et al. 2014b)

the Bathonian stage of the Middle Jurassic; and SQ5 corresponds to the Callovian stage of the Middle Jurassic.

\subsection{Paleogeography and coal accumulation of the Early and Middle Jurassic in the North and Northwest China CAAs}

In the Early and Middle Jurassic of the North and Northwest China CAAs, the mineable thick coal seams were mostly developed in SQ2 and SQ3 (Liu et al. 2013; Wang and Shao 2013). The paleogeography of these two sequences was reconstructed based on the analysis of outcrop and borehole sections.

\subsubsection{Lithofacies paleogeography and coal-accumulation of SQ1}

SQ1 corresponds to the lower part of the Lower Jurassic coal-bearing strata (Wang and Shao 2013). The paleogeographic units and sedimentary facies developed in each sedimentary basin mainly include alluvial fan, fluvial plain, delta and lacustrine facies (Zhang et al. 1997; Zhang et al. 1998) (Fig. 13).

In the Junggar Basin, the coal-rich belts are mainly distributed along the marginal areas of the basin. In the northern marginal areas, such as the Teli-Hoxtolgay coalfield and the Karamay coalfield, the total thickness of coal seams is generally $0.8-41.77 \mathrm{~m}$. In the central part of the Teli and Hoxtolgay coalfield, the coal seams are thicker and relatively stable, and in contrast, the coal seams in the 


\begin{tabular}{|c|c|c|c|c|c|c|c|c|c|c|c|}
\hline$\stackrel{\mathscr{E}}{\stackrel{0}{0}}$ & Stage & $\begin{array}{l}\text { Junggar } \\
\text { Basin }\end{array}$ & $\begin{array}{l}\text { Yili } \\
\text { Basin }\end{array}$ & $\begin{array}{l}\text { Turpan- } \\
\text { Hami } \\
\text { Basin }\end{array}$ & $\begin{array}{l}\text { Kuqa- } \\
\text { Manjar } \\
\text { Basin }\end{array}$ & $\begin{array}{l}\text { Tuoyun- } \\
\text { Hetian } \\
\text { Qiemo- } \\
\text { Minfeng }\end{array}$ & $\begin{array}{l}\text { Qaidam } \\
\text { Basin }\end{array}$ & $\begin{array}{l}\text { Western } \\
\text { Qilian } \\
\text { Mountain } \\
\text { Basins }\end{array}$ & $\begin{array}{c}\text { Chaoshui } \\
\text { Basin }\end{array}$ & $\begin{array}{l}3 \text { rd-order } \\
\text { sequence }\end{array}$ & $\begin{array}{l}\text { Base } \\
\text { level } \\
\text { cycle }\end{array}$ \\
\hline 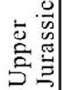 & Oxfordian & Qigu Fm & Qigu Fm & Qigu Fm & Qigu Fm & $\begin{array}{l}\text { Kuzigongst } \\
\text { Fm }\end{array}$ & $\begin{array}{l}\text { Caishiling } \\
\text { Fm }\end{array}$ & $\begin{array}{l}\text { Xiangtans } \\
\text { Fm }\end{array}$ & $\begin{array}{l}\text { Shazaohe } \\
\text { Fm }\end{array}$ & & \\
\hline \multirow{3}{*}{ 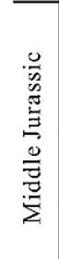 } & Callovian & \multirow{2}{*}{$\begin{array}{l}\text { Toutunhe } \\
\text { Fm }\end{array}$} & \multirow{2}{*}{$\begin{array}{l}\text { Aiweier- } \\
\text { gou } \\
\text { Group }\end{array}$} & $\begin{array}{l}\text { Qiketai } \\
\text { Fm }\end{array}$ & \multirow{2}{*}{$\begin{array}{l}\text { Qiakemake } \\
\text { Fm }\end{array}$} & \multirow{2}{*}{ Taerga Fm } & \multirow{2}{*}{$\begin{array}{l}\text { Shimengou } \\
\text { Fm }\end{array}$} & \multirow{2}{*}{$\begin{array}{l}\text { Jiangeang } \\
\text { Fm }\end{array}$} & \multirow{3}{*}{$\begin{array}{l}\text { Qingtujing } \\
\text { Group }\end{array}$} & SQ5 & \\
\hline & Bathonian & & & $\begin{array}{l}\text { Sanjian- } \\
\text { fang Fm }\end{array}$ & & & & & & $\mathrm{SQ4}$ & \\
\hline & Bajocian & $\begin{array}{l}\text { Xishanyao } \\
\text { Fm }\end{array}$ & $\begin{array}{l}\text { Hujiertai } \\
\text { Fm }\end{array}$ & $\begin{array}{l}\text { Xishanyao } \\
\mathrm{Fm}\end{array}$ & $\begin{array}{l}\text { Kezilenur } \\
\mathrm{Fm}\end{array}$ & $\begin{array}{l}\text { Yangye } \\
\text { Fm }\end{array}$ & $\begin{array}{l}\text { Dameigou } \\
\text { Fm }\end{array}$ & Muli Fm & & $\mathrm{SQ3}$ & \\
\hline \multirow{4}{*}{ 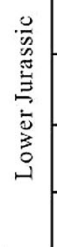 } & Toarcian & \multirow{2}{*}{$\begin{array}{l}\text { Sangonghe } \\
\text { Fm }\end{array}$} & \multirow{2}{*}{$\begin{array}{l}\text { Jirentai } \\
\text { Fm }\end{array}$} & \multirow{2}{*}{$\begin{array}{l}\text { Sangonghe } \\
\text { Fm }\end{array}$} & \multirow{2}{*}{$\begin{array}{l}\text { Yangxia } \\
\text { Fm }\end{array}$} & \multirow{2}{*}{$\begin{array}{l}\text { Kangsu } \\
\text { Fm }\end{array}$} & \multirow{5}{*}{$\begin{array}{l}\text { Xiaomeigou } \\
\text { Fm }\end{array}$} & \multirow{5}{*}{ Reshui Fm } & \multirow{5}{*}{$\begin{array}{l}\text { Jijigou } \\
\text { Group }\end{array}$} & \multirow{2}{*}{$\mathrm{S} Q 2$} & \\
\hline & $\begin{array}{l}\text { Pliensba- } \\
\text { chian }\end{array}$ & & & & & & & & & & \\
\hline & Sinemurian & \multirow{2}{*}{$\begin{array}{l}\text { Badaowan } \\
\text { Fm }\end{array}$} & \multirow{2}{*}{$\begin{array}{l}\text { Suasuhe } \\
\text { Fm }\end{array}$} & \multirow{2}{*}{$\begin{array}{l}\text { Badaowan } \\
\mathrm{Fm}\end{array}$} & Ahe Fm & \begin{tabular}{|l|} 
Salitash \\
Fm
\end{tabular} & & & & \multirow{2}{*}{ SQ1 } & \\
\hline & Hettangian & & & & \begin{tabular}{|l|} 
Taliqike \\
\end{tabular} & & & & & & \\
\hline 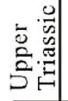 & Rhetian & $\begin{array}{l}\text { Haojiagou } \\
\text { Fm }\end{array}$ & $\begin{array}{l}\text { Haojiagoy } \\
\text { Fm }\end{array}$ & $\begin{array}{l}\text { Haojiagou } \\
\text { Fm }\end{array}$ & $\begin{array}{l}\text { Haojiagou } \\
\text { Fm }\end{array}$ & & & & & & \\
\hline
\end{tabular}

Fig. 12 Scheme of subcorrelation of the third-order sequences of the Jurassic in the Northwest China CAA

Karamay coalfield is thinner and less stable. In the southern margin of the basin, the total coal seam thickness is generally $0.5-69.77 \mathrm{~m}$, and in the southern Junggar coalfield and the Houxia coalfields, the coal seams are thicker and relatively stable, with a relatively simple structure. In the east margin of the basin, the coal seams are $0.25-26.65 \mathrm{~m}$ in thickness. The coal seams in this sequence were mainly deposited in the swamp of delta plain environments.

In the Turpan-Hami Basin, the total thickness of coal seams is generally $0-81.86 \mathrm{~m}$, coal-rich belts are located in the Aiweiergou, Qiquanhu, Shanshan and the Sandaoling areas, and the thickest coal seams are located in the Aiweiergou mining area with the maximum coal thickness reaching $81.86 \mathrm{~m}$. Inter-delta bay environment was the most favorable coal-forming environment, followed by delta plain and braided fluvial plain.

In the Tarim Basin, coals are mainly distributed in the northern and southern part of the Basin. In the northern part, the coal seams are 2.3-28.99 $\mathrm{m}$ in thickness and mainly distributed in the Wensu coalfield, the Kuqa-Baicheng coalfield and the Yangxia coalfields, in which the Kuqa-Baicheng coalfield was developed with the best coalforming environment, with the average coal thickness being $28.99 \mathrm{~m}$ and the coal thickness percentage being as high as $12.6 \%$. The meandering fluvial delta environments were responsible for the deposition of these coals. In the southwestern margin of the Tarim Basin, basically no coal was developed during this period.
In the Chaoshui Basin, the thickness of the coal seams of SQ1 is generally $1-3 \mathrm{~m}$ and three coal-accumulating centers are identified, including Pingshanhu, Hongshagang and Xiqu depressions. The coal seams in the Pingshanhu depression have the largest thickness, reaching $5.4 \mathrm{~m}$, and they were thinning out towards the northwest. In the Xiqu depression, the coal seam thickness is between 0.6 and $2.7 \mathrm{~m}$, and gradually thins out towards the southeast. In the Hongshagang depression, coal seam thickness ranges between 1.5 and $2.5 \mathrm{~m}$ and thins out towards the south. During this period, the favorable coal-accumulating environments were associated with the braided fluvial delta plain.

In the Qilian Mountains Basin, the Reshui mining area was developed with the coals of SQ1, with the coal seam thickness ranging between 0.35 and $27.78 \mathrm{~m}$. Although the coal seams are thick, the spatial distribution is limited and mainly restricted in the area of delta plain environments.

In the northern Qaidam Basin, coals in SQ1 were mainly restricted in the Dameigou mining area and the Mangya area. The distribution of coals in the Dameigou mining area is limited, and 4 coal seams were developed, namely A, B, $\mathrm{C}$, and $\mathrm{D}$ coal seam groups. The coals in this area were mainly developed in the braided delta plain environments, with the thickness of coal seam ranging between 0.23 and $10 \mathrm{~m}$. The coal seams are laterally stable, with the thickness increasing from the periphery to the center of the basin. The Mangya area is located in the western part of the northern Qaidam Basin, and the coals developed in this 


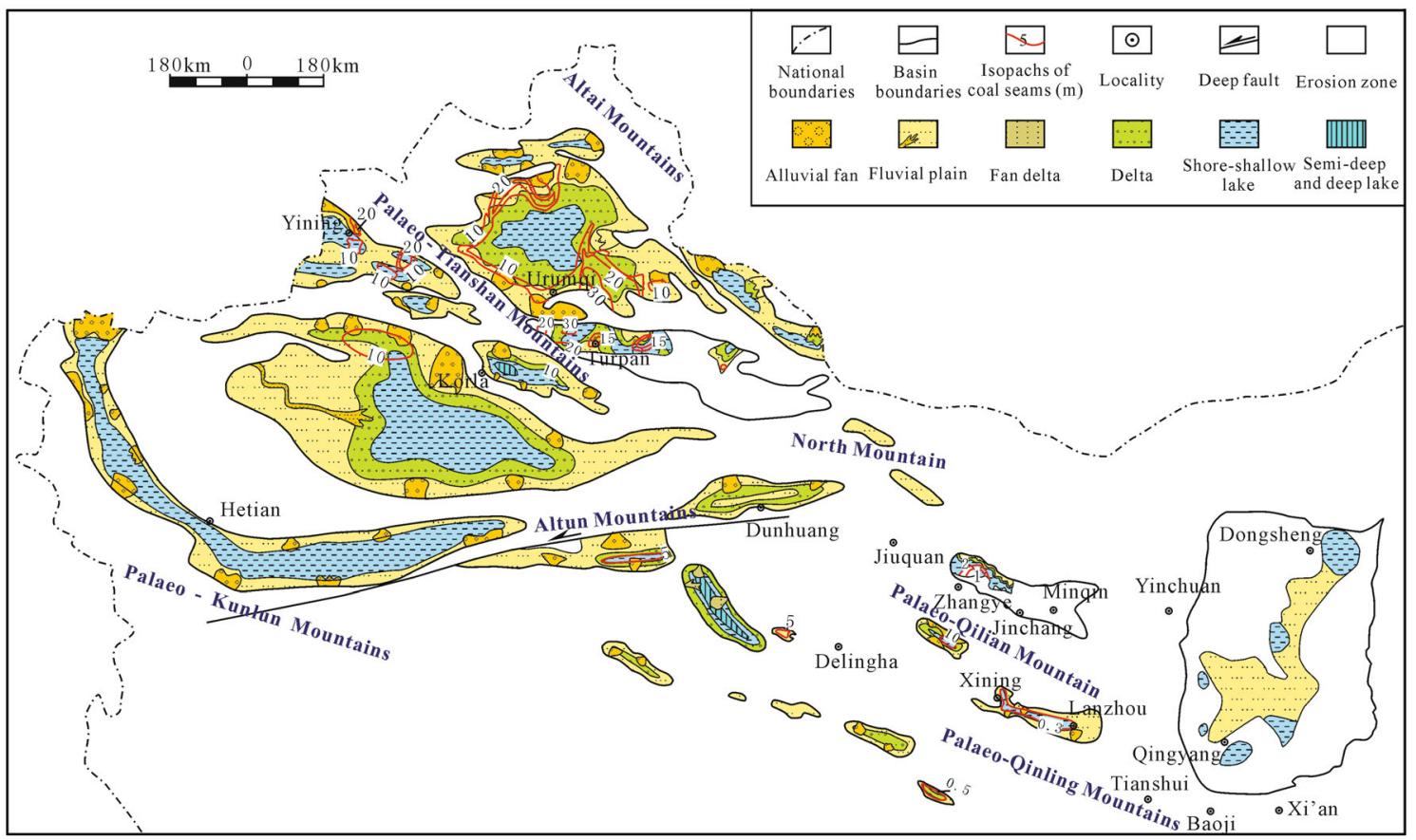

Fig. 13 Paleogeography and distribution of coal seams of SQ1 of the Early-Middle Jurassic in the North China CAA and Northwest CAA

area are unstable and laterally discontinuous. Most coals were accumulated in the fluvial, alluvial fan, and lacustrine environments. Thickness of local thick coal seams can reach $20 \mathrm{~m}$.

In the Ordos Basin, the Fuxian Formation of SQ1 is dominated by the purple-red mudstones and coarse-grained clastic rocks, with lithology and facies varying greatly, and no minable coal was formed.

\subsubsection{Lithofacies paleogeography and coal-accumulation of $S Q 3$}

SQ3 corresponds to the Bajocial and Aalenian stages of the Middle Jurassic, and is one of the major Jurassic coalbearing sequences. During this period, the North and Northwest China CAAs experienced a warm and humid climate, and were widely developed with the lacustrine facies in association with further expansion of stratigraphic distribution (Fig. 14).

In the Junggar basin, the coal seams in the northern part were concentrated in the Teli-Hoxtolgay coalfield and Karamay coalfield with a total thickness of about $15.04-45.08 \mathrm{~m}$. The coal seams in the southern margin of the basin generally have a total thickness of 6.07$188.59 \mathrm{~m}$, and the thickest total coal seams can be up to $200 \mathrm{~m}$ in the southern Junggar Basin around Urumqi. The coal seams in the eastern part of the basin are characterized by a wide distribution, with the total thickness generally between 0.35 and $111.43 \mathrm{~m}$, and the thickest coal seam is distributed in the Jiangjunmiao area. Coals in the Junggar Basin were mainly formed in the upper delta plain (Wang and Shao 2013).

In the Turpan-Hami Basin, the early stage of SQ3 was dominated by shallow-water delta environments that favorable for coal accumulation. The total coal seam thickness is generally $0.2-314.53 \mathrm{~m}$, with the coal-accumulating centers being located in the Kerjian, Taoshuyuan, Taoshuyuan-Kekeya, eastern Qiketai, Aidinghu, Shaerhu, Dananhu and Sandaoling areas (Zhang et al. 1997). The late stage of SQ3 was dominated by the relatively deep water environments that favored the development of lake environment and were not favorable for coal accumulation.

In the Tarim Basin, the coal seams in the northern part of the basin were $0.57-36.73 \mathrm{~m}$ thick and were mainly distributed in Wensu, Kuqa-Baicheng, Yangxia area. The coal seams in the southwest margin of the basin were mainly distributed in the Shache-Yecheng area, with the total thickness reaching $29.01 \mathrm{~m}$. Coals in the Tarim Basin were mainly formed in the delta plain and fluvial plain environments.

In the Chaoshui Basin, the total coal seam thickness is generally $1-10 \mathrm{~m}$ with an average of $5 \mathrm{~m}$. There are three coal-accumulating centers, namely the Pingshanhu, Hongshagang and Hongliuyuan depression area. Coal seam thickness in the Pingshanhu depression is generally 1-6 m. The maximum thickness of coal seams in the Hongshagang depression is $18 \mathrm{~m}$. The coal seam thickness in the Hongliuyuan depression area is $1-6 \mathrm{~m}$, with an average of 


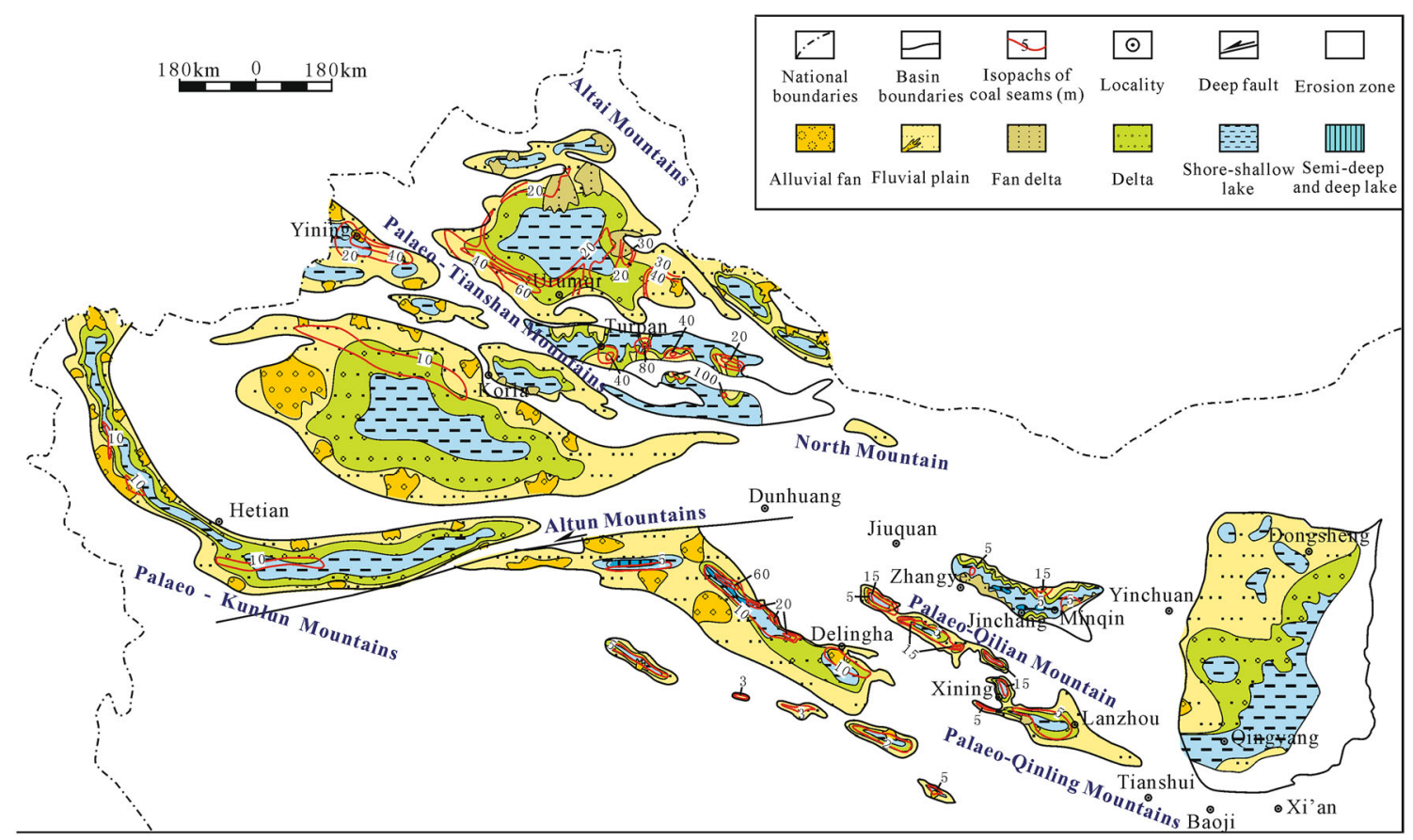

Fig. 14 Paleogeography and distribution of coal seams of SQ3 of the Early-Middle Jurassic in the North China CAA and Northwest CAA

$3 \mathrm{~m}$. The favourable environments for coal accumulation were braided delta plain, fan delta plain and littoral lake.

In the Qilian Mountains Basin, all basins are developed with coal seams. The total coal thickness in Chaidaer mine of the Reshui mining area is more than $100 \mathrm{~m}$. The coal seam in the Datong mining area of the Menyuan coalfield is thicker and pinching out outward.

In the northern Qaidam Basin, coal seams in SQ3 were well developed in whole area, with thickness ranging between 0.51 and $38.86 \mathrm{~m}$ in the Laogaoquan, Yukia, and Dameigou mining areas. The lateral variation of coal seam thickness was decreasing from southeast to northwest, and the area with coals thicker than $20 \mathrm{~m}$ was extended from southeast to northeast. Fluvial-delta sedimentary system was widely distributed and the coal-forming swamps were developed in the interdistributary bay environments of the delta plain (Liu et al. 2013).

In the Ordos Basin, SQ3 is represented by the wellknown Yan'an Formation of the early Middle Jurassic, in which the major minable coals were well developed (Wang 1996a; Wang et al. 2012). There are multiple layers of minable coal seams in the western part of the basin (eastern Ningxia and eastern Gansu) and the northern part of the basin (around Dongsheng area of Inner Mongolia, and the Shenmu area of Shaanxi), with total coal thickness ranging between 5 and $50 \mathrm{~m}$ and the local thickest seams reaching $70 \mathrm{~m}$ in the Huating coal mine of eastern Gansu (Shao et al. 2020). The number of coal seams and total coal thickness both decrease towards the south and the east.
However, the thickness of a single coal seam in the southern part can be up to $5-10 \mathrm{~m}$.

\section{Sequence stratigraphic framework and the coal accumulation of the Early Cretaceous in the Northeast China CAA}

\subsection{Sequence stratigraphic framework of the Early Cretaceous coal-bearing strata}

\subsubsection{Stratigraphy and depositional environments}

The Early Cretaceous is an important coal-accumulating period in the geologic history, and during this period, abundant coal resources were formed in the continental rifting basins in the Northeast China CAA. The Northeast China CAA can be subdivided into 3 sub-zones from west to east, including western sub-zone, central sub-zone, and eastern sub-zone. The western sub-zone is located at the west side of Da Hinggan Mountains, and includes Erlian Basin and Hailaer Basin. The coal-bearing strata in this sub-zone include, from bottom to top, the Aershan, Tengger, and Saihantala Formations in the Erlian Basin, and the Longjiang, Damoguaihe, and Yiming Formations in Hailaer Basin. The central sub-zone is located in the Songliao Basin, which is between the Da Hinggan Mountains to the west and the Yilan-Yitong fault zone to the east. The typical coal-bearing strata in the Songliao Basin include, from bottom to top, the Huoshiling, Shahezi, and 
Yingcheng Formations. The eastern sub-zone is mainly located at the east part of Heilongjiang Province and Jilin Province, and is typically represented by the SanjiangMuling Basin. The typical coal-bearing strata in this subzone include, from bottom to top, the Didao, Chengzihe, and Muling Formations. The stratigraphic correlation of these lithological stratigraphic units can be seen in Fig. 15. All these Formations are composed of coal and non-marine siliciclastic rocks, including mudstone, shale, siltstones, sandstones and conglomerates. A total of 6 depositional systems are identified, including alluvial fan, fan delta, fluvial plain, meandering river delta, sublittoral lake and profundal lake (Shao et al. 2013a).

\subsubsection{Sequence stratigraphy}

The sequence stratigraphic framework of the Northeast China CAA has been established based on the recognized sequence boundaries, including regional unconformity surface, erosional base of incise valley fill sandstone/conglomerates, inter-fluvial paleosol horizons, and vertical facies reversal surface. The coal-bearing strata in the Northeast China CAA can be subdivided into 5 third-order sequences (Shao et al. 2013a), and the sub-correlation of these sequences with the lithological formations can be seen in Fig. 15. As the Early Cretaceous spanned from 139 to $125 \mathrm{Ma}$, and lasted for $14 \mathrm{Ma}$ (ICS 2018), and assuming the depositional hiatus of sequence boundaries last for dozens of millions years, then the duration time of these sequences can be estimated as roughly less than $4 \mathrm{Ma}$, corresponding well with the third-order sequence raised by Vail et al. (1977).

SQ1 corresponds to the Aershan Formation, which is equivalent to the Jiufotang Formation in Erlian Basin, the Huoshiling Formation in Songliao Basin, or the Didao Formation in Sanjiang-Muling Basin. SQ2 and SQ3 correspond to the Tenggeer Formation, which can be correlated to Member 1 and Member 2 in the Shahai Formation in the Erlian Basin, the Damoguaihe Formation in the Hailaer Basin, the Shahezi Formation in the Songliao Basin, or the Chengzihe Formation in the Sanjiang-Muling Basin. SQ4 and SQ5 correspond to the Saihantala Formation, which can be correlated to Member 1 and Member 2 of the Fuxin Formation in the Erlian Basin group, the Yimin Formation in the Hailaer Basin, the Yingcheng Formation in the Songliao Basin, or the Muling Formation in the Sanjiang-Muling Basin. From the perspective of the basin tectonic evolution, SQ1 was developed at the initial subsiding stage, SQ2 and SQ3 were developed during the stable subsiding stage, SQ4 and SQ5 were developed during the basin shrinkage stage. Coal accumulation is controlled by the tectonic evolution in the rifting basins. During the periods of SQ1, SQ4 and SQ5, the tectonic activities including volcanic activities were intense, so coal seams were not easy to be accumulated. In contrast, during the periods of SQ2 and SQ3, the relative balance between increasing rate of accommodation induced by the tectonic subsidence and peat accumulating rate favored the accumulation of regional thick coal seams. These 2 sequences correspond to the lower coal seams and the upper coal seams respectively. In spite of this overall regularity of coal distribution, the thick coal seams can also be accumulate in SQ4 and SQ5 in some individual basins under suitable paleoclimate and paleotectonic conditions, for instance 2 coal seams were accumulated in SQ5 of the Hegang Sub-Basin of the Sanjiang-Muling Basin.

\subsection{Paleogeography and coal accumulation of the Early Cretaceous coal-bearing strata in the Northeast China CAA}

The lithofacies paleogeographic maps of 3rd-order sequences were reconstructed based on the contours of lithological parameters (strata thickness, mudstone thickness, coarse/fine ratios, total coal thickness). Reconstructed paleogeographic units mainly include alluvial fan, fluvial plain, delta plain, sublittoral lake, and profundal lake, as presented in Fig. 16.

The coal accumulation characteristics in the Northeast China CAA were studied based on paleogeography and paleotectonics. During the Early Cretaceous, the paleopacific plate subducted beneath the continental plate, resulting in the forming of a series of NE trending fault basins (Wang et al. 2007). In the western sub-zone, to the west of the Da Hinggan Mountains, the tectonic activities were relatively weak and beneficial for the accumulation of thick coal seams. In the central sub-zone, represented by the Songliao Basin, the intensity of tectonic movements and volcanic activities were strong, therefore the coals were thinner compared to the western sub-zone (Guo et al. 2018; Wang et al. 2019, 2020). The regional differences of tectonic setting between the east and west of Da Hinggan Mountains was closely related to subduction zone migration of the paleo-Pacific plate. The east part including central and eastern sub-zones was closer to the subduction zone, and the tectonic subsidence was stronger, not as stable as the western sub-zone. As a result of the differentiated regional tectonic setting, the western sub-zone is typified by super-thick coal seams, the central sub-zone is developed with the intercalation of thick coals and thick layers of siliciclastic rocks, and the eastern sub-zone is developed with the intercalation of thin but minable coals and thick layers of fine-grained siliciclastics (Shao et al. 2013a). Generally, during the Early Cretaceous, most region of the Northeast China CAA was dominated by a humid and warm climate and the coal-rich belts were 


\begin{tabular}{|c|c|c|c|c|c|c|c|c|c|c|c|c|c|}
\hline \multirow{2}{*}{ 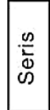 } & \multirow{2}{*}{\multicolumn{2}{|c|}{ Stage }} & \multirow{2}{*}{ 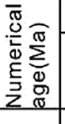 } & \multicolumn{2}{|c|}{ Inner Mongolia } & \multicolumn{2}{|c|}{ Liaoning } & \multicolumn{2}{|c|}{ Jilin } & \multicolumn{3}{|c|}{ Heilongjiang (HLJ) } & \multirow[t]{2}{*}{ Sequence } \\
\hline & & & & \multirow{2}{*}{$\begin{array}{l}\begin{array}{l}\text { Erlian } \\
\text { Basin } \\
\text { group }\end{array} \\
\begin{array}{l}\text { Erlian } \\
\text { Fm }\end{array}\end{array}$} & \begin{tabular}{|l|} 
Hailaer \\
Basin \\
group \\
\end{tabular} & \begin{tabular}{c|} 
West \\
Liaoning
\end{tabular} & $\begin{array}{c}\text { East } \\
\text { Liaoning }\end{array}$ & \multicolumn{2}{|l|}{$\begin{array}{l}\text { Songliao } \\
\text { Basin }\end{array}$} & West HLJ & \multicolumn{2}{|c|}{$\begin{array}{l}\text { Sanjiang- } \\
\text {-Mulenghe }\end{array}$} & \\
\hline \multirow{3}{*}{ 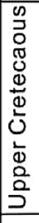 } & Cenomanian & $\begin{array}{l}\text { Qing- } \\
\text { shan- } \\
\text { kou K }_{2}\end{array}$ & \multirow{3}{*}{$\begin{array}{l}100^{-} \\
113\end{array}$} & & & & & $\begin{array}{l}\text { Qingshan } \\
\text { kou Fm }\end{array}$ & & & & & \\
\hline & Albian & $\begin{array}{l}\text { Quan- } \\
\text { tou }\end{array}$ & & & & & \multirow[b]{2}{*}{ Dayu Fm } & $\begin{array}{l}\text { Quantou } \\
\text { Fm }\end{array}$ & & & & & \\
\hline & Aptian & $\begin{array}{c}\text { Sunjia- } \\
\text { wan } \\
K_{i}^{j} \\
\end{array}$ & & & & $\begin{array}{l}\text { Sunjiawan } \\
\mathrm{Fm}\end{array}$ & & $\begin{array}{l}\text { Denglouku } \\
\text { Fm }\end{array}$ & & & \multicolumn{2}{|c|}{ Dongshan Fm } & \\
\hline \multirow{6}{*}{ 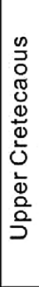 } & Barremian & Fuxin & \multirow{5}{*}{$\begin{array}{l}129 \\
132\end{array}$} & $\begin{array}{l}\text { Saihan- } \\
\text { tala Fm }\end{array}$ & Yimin Fm & \multirow{2}{*}{ Fuxin Fm } & \multirow{4}{*}{$\begin{array}{l}\text { Nieerku } \\
\text { Fm }\end{array}$} & Yingcheng & \multirow{2}{*}{$\begin{array}{l}\text { Quanshui- } \\
\text { cun Fm }\end{array}$} & Xigangzi & \multirow{2}{*}{$\begin{array}{l}\text { Muleng } \\
\mathrm{Fm}\end{array}$} & \multirow{2}{*}{$\begin{array}{l}\text { Zhushan } \\
\text { Fm }\end{array}$} & Sq5 \\
\hline & & & & & 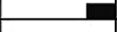 & & & & & & & & $\mathrm{Sq} 4$ \\
\hline & Hauterivian & Shahai & & Tengge- & Damo- & Shahai & & Shahezi & Changcai & & Chengzi & Yunshan & $\mathrm{Sq} 3$ \\
\hline & 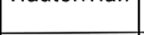 & $K_{1}^{3}$ & & & & $\mathrm{Fm}$ & & & & & he Fm & & Sq2 \\
\hline & Valanginian & $\begin{array}{l}\text { Jiufo- } \\
\text { tang } \\
\mathrm{K}_{\mathrm{i}}^{2} \\
\end{array}$ & & $\begin{array}{l}\text { Aershan } \\
\text { Fm }\end{array}$ & $\begin{array}{l}\text { Longjiang } \\
\text { Fm }\end{array}$ & $\begin{array}{l}\text { Jiufotang } \\
\text { Fm }\end{array}$ & $\begin{array}{l}\text { Lishugou } \\
\text { Fm }\end{array}$ & $\begin{array}{l}\text { Huoshiling } \\
\text { Fm }\end{array}$ & $\begin{array}{l}\text { Tuntian } \\
\text { ying }\end{array}$ & $\begin{array}{l}\text { Jiufeng- } \\
\text { shan Fm }\end{array}$ & $\begin{array}{l}\text { Didaoo } \\
\text { Fm }\end{array}$ & $\begin{array}{l}\text { Peide } \\
\text { Fm }\end{array}$ & $\mathrm{Sq} 1$ \\
\hline & Berriasian & $\begin{array}{c}\text { Yixian } \\
K^{\prime}\end{array}$ & 145 & & & $\begin{array}{l}\text { Yixian } \\
\text { Fm }\end{array}$ & $\begin{array}{l}\text { Xiaoling } \\
\text { Fm }\end{array}$ & & & $\begin{array}{l}\text { Shangkuli } \\
\text { /Aergong }\end{array}$ & & & \\
\hline
\end{tabular}

Fig. 15 The stratigraphic correlation and sequence stratigraphic framework of the Early Cretaceous in the Northeast China CAA. Revised from Wang et al. (1997), Sun and Zheng (2000), Shao et al. (2013a, b)

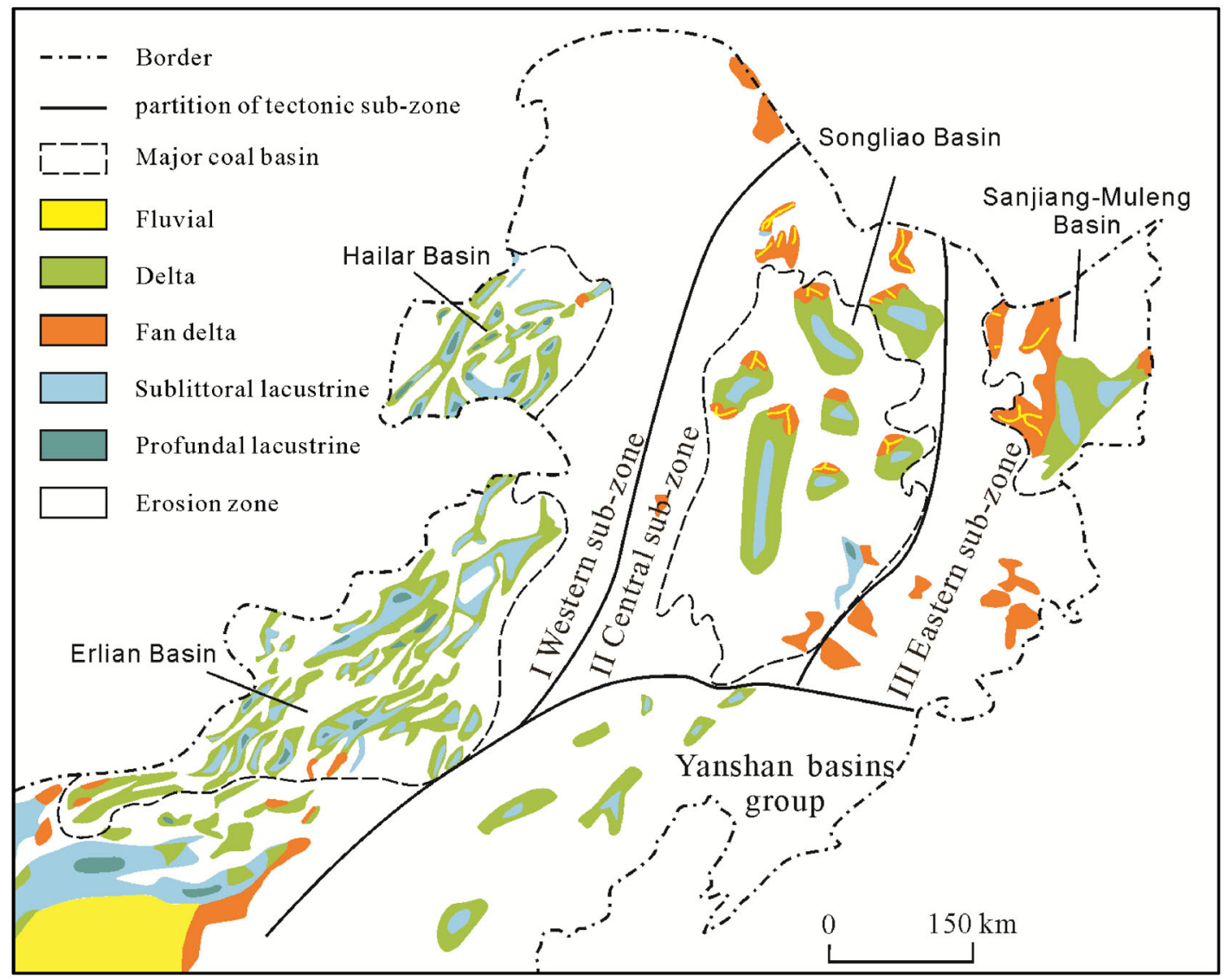

Fig. 16 Basin distribution and paleographic map of the Early Cretaceous coal-accumulating period in the Northeast China CAA

mainly formed in the alluvial fan, fluvial plain, delta, and sublittoral lake environments (Shao et al. 2013a). Alluvial fan-delta sedimentary system was always developed along the steep-sloped side of a rifting basin while the delta and lacustrine sedimentary system were developed in the gentle-slope side which was more suitable for coal accumulation (Wang et al. 2019). 


\section{Conclusions}

(1) Facies type, coal-accumulating models, and coalforming characteristics were summarized for the major coal-accumulating periods in China. In overall, the coal accumulation during Carboniferous to Permian were mainly developed in epicontinental settings which were dominated by transitional marine and continental environments such as fluvialdelta, tidal flat, lagoons, fluvial plains. In contrast, the coal-accumulating environments of the Mesozoic were mainly continental, including alluvial fan, fan delta, braided river or meandering fluvial, fluvial deltas, littoral and sublittoral lacustrine environments.

(2) The isochronous sequences stratigraphic framework of the major coal-accumulating periods is established, and the sub-correlation scheme of the thirdorder sequences is put forward. The CarboniferousPermian coal-bearing strata in the North China CAA are subdivided into 7 third-order sequences; the Late Permian coal-bearing strata in the South China CAA are subdivided into 3 third-order sequences; the Late Triassic coal-bearing strata in the South China CAA are subdivided into 5 third-order sequences; the Early-Middle Jurassic coal-bearing strata in the North and Northwest China CAAs are subdivided into 5 third-order sequences; and the Early Cretaceous coal-bearing strata in the Northeast China CAA are subdivided into 5 third-order sequences. Thick coal seam distribution characteristics and migration patterns of these major coal-accumulation periods in the sequence framework have certain regularities.

(3) The lithofacies paleogeographic maps of third-order sequences of the major coal-accumulating periods were reconstructed. The favorable coal-accumulating paleogeographic units of the Carboniferous and Permian coal-accumulating periods were lagoon, tidal flat, delta plain and fluvial plain. The favorable coal-accumulating paleogeographic units of the Mesozoic coal-accumulating periods were braided river delta plain, deltaic bay, and the lacustrine bay. Distribution of the coal-rich belts in each basin was predicted according to the distribution of favorable coal-accumulating paleogeographic units.

Acknowledgements This research was supported by the Project for the Survey of Land and Resources in China (1212010633901), National Natural Science Foundation of China (Grant No. 41572090), Yue Qi Scholar Funds of China University of Mining and Technology (Beijing), and Fundamental Research Funds for Central Universities of China University of Mining and Technology (Beijing).
Open Access This article is licensed under a Creative Commons Attribution 4.0 International License, which permits use, sharing, adaptation, distribution and reproduction in any medium or format, as long as you give appropriate credit to the original author(s) and the source, provide a link to the Creative Commons licence, and indicate if changes were made. The images or other third party material in this article are included in the article's Creative Commons licence, unless indicated otherwise in a credit line to the material. If material is not included in the article's Creative Commons licence and your intended use is not permitted by statutory regulation or exceeds the permitted use, you will need to obtain permission directly from the copyright holder. To view a copy of this licence, visit http://creativecommons. org/licenses/by/4.0/.

\section{References}

Bohacs K, Suter J (1997) Sequence stratigraphic distribution of coaly rocks: fundamental controls and paralic examples. AAPG Bull $81: 1612-1639$

Catuneanu O (2006) Principles of sequence stratigraphy. Elsevier, Amsterdam, pp 1-375

Chen ZH, Wu FD, Zhang SL, Zhang NM, Ma JX, Ge LG (1993) The depositional environments and coal-accumulating regularities of late paleozoic coal-bearing measures in North China. China University of Geosciences Press, Wuhan, pp 1-168

Cheng A, China National Administration of Coal Geology (2001) Analysis of coal accumulation system in china. China University of Mining and Technology Press, Xuzhou, pp 1-343 (in Chinese)

Cheng A, China National Administration of Coal Geology (2016) China occurrence regularity of coal resources and resource evaluation. Science Press, Beijing, pp 1-352 (in Chinese)

China Statistic Department (2019) China statistics yearbook. http:// data.stats.gov.cn/easyquery.htm? $\mathrm{cn}=\mathrm{C} 01$. (in Chinese)

Diessel CFK (1992) Coal-bearing depositional systems. Springer, Berlin, pp 1-599

ECDES (Editorial Committee of The Dictionary of Earth Science) (2005) The dictionary of earth science (volume of applied subject). Geological Publishing House, Beijing, pp 1-1201 (in Chinese)

Feng ZZ (2004) Single factor analysis and multi-factor comprehensive mapping method-reconstruction of quantitative rocks paleogeography. J Palaeogeogr 6:3-19 (in Chinese with English abstract)

Feng ZZ, Zheng XJ, Bao ZD, Jin ZK, Wu SH, He YB, Peng YM, Yang YQ, Zhang JQ, Zhang YS (2014) Quantitative lithofacies palaeogeography. J Palaeogeogr Engl 3(1):1-34

Fielding CR (1987) Coal depositional models for deltaic and alluvial plain sequences. Geology 15(7):661-664

Guo B, Shao LY, Hilton J, Wang S, Zhang L (2018) Sequence stratigraphic interpretation of peatland evolution in thick coal seams: examples from Yimin Formation (Early Cretaceous), Hailaer Basin, China. Int J Coal Geol 196:211-231

Han DX (1996) Coal petrology of China. China University of Mining and Technology Press, Beijing, pp 1-559 (in Chinese)

Han DX, Yang Q (1980) Coalfield geology of China, vol 2. China Coal Industry Press, Beijing, pp 1-415 (in Chinese)

Holz M, Kalkreuth W, Banerjee I (2002) Sequence stratigraphy of paralic coal-bearing strata: an overview. Int $\mathrm{J}$ Coal Geol 48:147-179

Horne JC, Ferm JC, Caruccio FT, Baganz BP (1978) Depositional models in coal exploration and mine planning in Appalachian region. AAPG Bull 62:2379-2411 
Hsieh CY (1949) Palaeogeography as a guide to mineral exploration. Bull Geol Soc China 28(1-2):1-11

ICS (International Commission on Stratigraphy) (2018) International Chronostratigraphic Chart. http://www.stratigraphy.org/ ICSchart/ChronostratChart2018-08.pdf

Jerrett RM, Davies RC, Hodgson DM, Flint SS, Chiverrell RC (2011) The significance of hiatal surfaces in coal seams. J Geol Soc Lond 168:629-632

Li ST (1988) Fault basin analysis and coal accumulation: an approach to sedimentation, tectonic evolution, and energy resource prediction in the late mesozoic fault basins of Northeastern China. Geological Publishing House, Beijing, pp 1-367 (in Chinese)

Li WH, China National Administration of Coal Geology (1999) Characteristics and coal accumulation of the Late Permian coal basin in South China. Jiangxi Science and Technology Publishing House, Jiangxi, pp 1-379 (in Chinese)

Li ZX, Wei JC, Wang MZ (1996) Sequence stratigraphic framework and sea level changes in the Late Paleozoic epicontinental basin in northern China. Sediment Facies Palaeogeogr 16(5):1-11 (in Chinese with English abstract)

Li ZX, Wei JC, Han ML (2001) Coal formation in transgressive events: a new pattern of coal accumulation. Adv Earth Sci 16(1):120-124 (in Chinese with English abstract)

Li YN, Shao LY, Fielding CR, Wang DW, Mu GY, Luo HH (2020) Sequence stratigraphic analysis of thick coal seams in paralic environments: a case study from the Early Permian Shanxi Formation in the Anhe coalfield, Henan Province, North China. Int J Coal Geol 222:103451

Liu HJ, Jia YR, Long YZ, Wang HW (1987) The features of the barrier island systems of the epeiric sea and their event deposits of coal bearing formations in Carboniferous of North China. Acta Sedimentol Sin 5(3):73-80 (in Chinese with English abstract)

Liu HJ, Zhang YJ, Wang HW, Jia YR, Long YZ (1991) Study on lithofacies paleogeography of coal-bearing formations of jungar coal field. Geological Publishing House, Beijing, pp 1-128 (in Chinese with English abstract)

Liu TJ, Shao LY, Cao DY, Ju Q, Guo JN, Lu J (2013) Formingconditions and resource assessment of Jurassic coal in Northern Qaidam Basin. Geological Publishing House, Beijing, pp 1-276 (in Chinese)

Mitchum Jr RM (1977) Seismic stratigraphy and global changes of sea level, part 11: glossary of terms used in seismic stratigraphy. In: Payton CE (ed) Seismic stratigraphy: applications to hydrocarbon exploration. Memoir of American Association of Petroleum Geologists, 26: 205-212

Peng SP (1990) Fundamental characteristics of the anastomosing fluvial system on complex deltaic plain. Chin Sci Bull 35(10):835-839

Qin Y (2017) An introduction to fossil energy geology. China University of Mining and Technology Press, Xuzhou, pp 1-436 (in Chinese)

Shang GX, China National Adiminisration of Coal Geology (1997) Late Paleozoic coal geology of North China Platform. Shanxi Science and Technology Press, Taiyuan, pp 1-405 (in Chinese with English abstract)

Shao LY, Zhang PF, Tian BL (1993) Sequence stratigraphy of coalbearing strata and sea-level fluctuation for the Late Permian in Zhina area, western Guizhou, China. Geosci Explor 8:1-10 (in Chinese with English abstract)

Shao LY, Lu J, Wang H, Zhang PF, Han DX (2008) Advances in sedimentology and sequence stratigraphy of paralic coal measures. J Palaeogeogr 10(6):561-570 (in Chinese with English abstract)
Shao LY, Lu J, Wang H, Zhang PF (2009) Developments of coal measures sequence stratigraphy in China. Acta Sedimentol Sin 27(5):904-914 (in Chinese with English abstract)

Shao K, Shao LY, Qu YL, Zhang Q, Wang J, Gao D, Wang DD, Li Z (2013a) Study of sequence stratigraphy of the Early Cretaceous coal measures in Northeastern China. J China Coal Soc 38(S2):423-433 (in Chinese with English abstract)

Shao LY, Gao CX, Zhang C, Wang H, Guo LJ, Gao CH (2013b) Sequence-paleogeography and coal accumulation of the Late Permian in the southwestern China. Acta Sedimentol Sin 31(5):856-866 (in Chinese with English abstract)

Shao LY, Dong DX, Li MP, Wang HS, Wang DD, Lu J, Zheng MQ, Cheng AG (2014a) Sequence-paleogeography and coal accumulation of the Carboniferous-Permian in the North China Basin. J China Coal Soc 39(8):1725-1734 (in Chinese with English abstract)

Shao LY, Li YJ, Jin FX, Gao CX, Zhang C, Liang WL, Li GM, Chen ZS, Peng ZQ, Cheng AG (2014b) Sequence: paleogeography and coal accumulation of the Late Triassic coal measures in the South China Plate. J Palaeogeogr 16(5):613-630 (in Chinese with English abstract)

Shao LY, Zhang C, Yan ZM, Dong DX, Gao CX, Li YJ, Xu XY, Liang WL, Yi TS, Xu XH, Li GM, Chen ZS, Cheng AG (2016) Sequence-palaeogeography and coal accumulation of the Late Permian in South China. J Palaeogeogr 18(6):905-919 (in Chinese with English abstract)

Shao LY, Wang XT, Lu J, Wang DD, Hou HH (2017) A reappraisal on development and prospect of coal sedimentology in China. Acta Sedimentol Sin 35(5):1016-1031 (in Chinese with English abstract)

Shao LY, Wang DD, Dong DX, Li MP, Li L (2020) Depositional environments and coal-accumulating regularities of the coalbearing series in Ordos Basin. Geological Publishing House, Beijing, pp 1-228 (in Chinese)

Shearer JC, Staub JR, Moore TA (1994) The conundrum of coal bed thickness: a theory for stacked mire sequences. J Geol 102:611-617

Sun G, Zheng SL (2000) New proposal on division and correlation of Mesozoic from northeastern China. J Stratigr 24(1):60-64 (in Chinese with English abstract)

Thomas L (2002) Coal geology. Wiley, Hoboken, pp 1-384

Vail PR, Mitchum Jr RM, Thompson III S (1977) Seismic stratigraphy and global changes of sea level, part 3: relative changes of sea level from coastal onlap. In: Payton CE (ed) Seismic stratigraphy: applications to hydrocarbon exploration. Memoir of American Association of Petroleum Geologists. 26: 63-81

Van Wagoner JC, Posamentier HW, Mitchum RM, Vail PM, Sarg JF, Loutit TS, Hardenbol J (1988) An overview of the fundamentals of sequence stratigraphy and key definitions. In: Wilgus CK, Hastings BS, Kendall CG et al (eds) Sea level changes: an integrated approach. SEPM Special Publication, 42: 39-46

Van Wagoner JC, Mitchum RM Jr, Campion KM, Rahmanian VD (1990) Siliciclastic sequence stratigraphy in well logs, cores, and outcrops: concepts for high resolution correlation of time and facies. AAPG Methods Explor Ser 7:1-55

Wang SM, China National Administration of Coal Geology (1996a) Coal accumulation and coal resource evaluation of ordos basin. Coal Industry Publishing House, Beijing, pp 1-437 (in Chinese)

Wang XC, China National Administration of Coal Geology (1996b) Sedimentary environments and coal accumulation of late permian coal formations in western Guizhou Southern Sichuan and Eastern Yunnan. Chongqing University Press, Chongqing, pp 1-277 (in Chinese)

Wang T, Shao LY (2013) Forming-conditions and resource assessment of Jurassic coals in Northwestern China. Geological Press of China, Beijing, pp 1-196 (in Chinese) 
Wang YQ, Su YZ, Liu EY (1997) Regional stratigraphy of northeastern china, multiple classification and correlation of stratigraphy of China. China University of Geosciences Press, Wuhan, pp 1-175 (in Chinese)

Wang CS, Chen HD, Shou JF, Li XH, Tian JC, Qin JX (1999) Sea level changes and uplifting events of the Late Pemian in southern China. Acta Sedimentol Sin 17(4):537-541 (in Chinese with English abstract)

Wang HZ, Shi XY, Wang XL, Yin HF, Qiao XF, Liu BP, Li ST, Chen JQ (2001) Research on the sequence stratigraphy of China. Gongdong Science and Technology Press, Guangzhou, pp 1-456 (in Chinese)

Wang GL, Ju YW, Zheng ML, Cao DY, Qin Y, Zhu YM (2007) Tectonics of energy resource basins in the Northern China. China University of Mining and Technology Press, Xuzhou, pp 1-541 (in Chinese)

Wang H, Shao LY, Hao LM, Zhang PF, Glasspool IJ, Wheeley JR, Wignall PB, Yi TS, Zhang MQ, Hilton J (2011) Sedimentology and sequence stratigraphy of the Lopingian (Late Permian) coal measures in southwestern China. Int J Coal Geol 85:168-183

Wang DD, Shao LY, Li ZX, Hu YH (2012) Sequence stratigraphic framework and coal formation of Yan'an Formation in Ordos Basin. J Jilin Univ (Earth Sci Ed) 43(6):1726-1739 (in Chinese with English abstract)

Wang DD, Shao LY, Liu HY, Shao K, Yu DM, Liu BQ (2016) Research progress in formation mechanisms of super-thick coal seam. J China Coal Soc 41(6):1487-1497 (in Chinese with English abstract)

Wang S, Shao LY, Wang DD, Sun QP, Sun B, Lu J (2019) Sequence stratigraphy and coal accumulation of Lower Cretaceous coalbearing series in Erlian Basin, northeastern China. AAPG Bull 103(7): 1653-1690

Wang S, Shao LY, Wang DD, Hilton J, Guo B, Lu J (2020) Controls on accumulation of anomalously thick coals: implications for sequence stratigraphic analysis. Sedimentology 67:991-1013

Yang Q, Han DX (1979) Coalfield geology in China, vol 1. China Coal Industry Press, Beijing, pp 1-261 (in Chinese)

Zhang T (1995) Depositional environments and coal accumulation of Chinese coal-accumulating periods. Geological Publishing House, Beijing, pp 1-273 (in Chinese)

Zhang PF, Peng SP, Shao LY, Liu QF (1993) Depositional environments of coal bearing successions. China Coal Industry Press, Beijing, pp 1-284 (in Chinese)

Zhang PF, Jin KL, Wu T, Wang CG (1997) Study on sedimentology and coal-derived oil from Jurassic coal-bearing series in TurpanHami basin, northwestern China. China Coal Industry Publishing House, Beijing, pp 1-269 (in Chinese)

Zhang H, Li HT, Xiong CW, Zhang H, Wang YD, He ZL, Lin GM, Sun BN (1998) Jurassic coal bearing strata and coal accumulation of Northwestern China. Geological Publishing House, Beijing, pp 1-418 (in Chinese) 